\title{
Walk the Talk-A Sustainability Management System for Social Acceptance in Nordic Mining
}

\author{
Helena Ranängen * and Åsa Lindman (1) \\ Department of Business Administration, Technology and Social Sciences, Luleå University of Technology, LTU, \\ 97187 Luleå, Sweden; asa.lindman@ltu.se \\ * Correspondence: helena.ranangen@ltu.se
}

Received: 16 March 2020; Accepted: 23 April 2020; Published: 25 April 2020

check for updates

\begin{abstract}
The mining industry has experienced increased stakeholder pressure over the last decades, and the legitimacy of the mining industry and its place in society is sometimes questioned. On the other hand, high corporate social responsibility (CSR) performance can lead to an increased social acceptance, which in the end may give the mining company the social license to operate. This article focuses on stakeholder management within management system thinking in order to enhance the social acceptance for mining. The purpose is to describe a mining company's existing stakeholder management practice and identify areas for improvement using established stakeholder management models to achieve an efficient and effective stakeholder management practice. The purpose is also to describe how conceptual sustainability management system (SMS) frameworks can be usefully applied and, more specifically, whether and how stakeholder management models and the concept of materiality analysis are useful for the planning step in an SMS for social acceptance. The findings show that the used SMS framework fits well in this context, and that a materiality analysis can beneficially be used for the 'systemization of stakeholder demands' in the planning step of an SMS.
\end{abstract}

Keywords: sustainability management system; CSR; corporate social responsibility; stakeholder management; social acceptance; mining

\section{Introduction}

Sustainable development is a widely accepted concept and a challenge for the mining industry. When talking about the corporate contribution to sustainable development, the concept of corporate social responsibility (CSR) is applicable, which is defined as the implementation of social and environmental concerns in a company's operations and its voluntary interactions with stakeholders [1]. The concept of CSR has flourished in the last two decades [2]. CSR research is comprehensive and focuses, among other things, on CSR strategy, various forms of self-regulation, supply chain management, and disclosures of environmental and social impacts [3]. Examples of recent research are presented by Ashrafi et al., who explore why and how CSR is integrated into business strategic decisions and operation processes in order to improve the viability of corporations [2]. Michelon et al. investigate different CSR reporting practices [3]. However, the concept of CSR is largely debated, but also applied differently from one geographical area to another, or from one company to another [4].

The extraction of natural resources has had a long-term social and environmental impact in many parts of the world [5]. The stakeholders, with their needs and expectations, are often found in the local community. The mining industry has experienced increased stakeholder pressure over the last decades, which means that stakeholders now have more specific views of what these 'social and environmental concerns' should consist of $[6,7]$. As a consequence, the mining industry is in the forefront concerning CSR [8]. 
Natural resource management conflicts and mineral related environmental conflicts can lead to heated discussions about the legitimacy of the mining industry and its place in society [9]. On the other hand, the way in which CSR is applied by companies is of major importance for increased social acceptance, which in the end may give the mining company the 'social license to operate' (SLO) [4]. Hence, the mining industry needs to create value for its stakeholders in order to gain social acceptance and obtain the SLO [10]. By understanding the local society and using its input for decision-making, the mining industry can develop its CSR practice further [11]. Mining companies can also use SLO as a risk management strategy to minimize risks by creating strategic forms of community involvement [12].

The concept of SLO is based on the perception that a company needs 'social permission' as well as government permission to conduct its business. The most common definition is that it issued when mining is seen as "having the broad, on-going approval and acceptance of society to conduct its activities" [13], which means that mining companies need to go above and beyond the legal and regulatory requirements [14]. SLO consists of different parts, depending on the conditions in place [15]. As projects are situational, and every community-company relationship is different, SLO is highly contextual [16]. The SLO concept is well-established in the mining sector as a significant element of the CSR's credibility [17].

In order to address societal expectations and obtain the SLO, business must become attuned to stakeholders' needs, concerns, and expectations [18]. A dialogue with stakeholders in the community leads to stronger relationships with mining company personnel, increased perceptions of procedural fairness, and, indirectly, trust in and a social acceptance of the mining industry [19]. Bice argues that it is important to bridge the gap between social license theory and CSR practice [18]. This is also confirmed in the study presented by Ranängen and Lindman, in which a stakeholder survey shows that stakeholders find self-regulatory practices, such as management systems, important in order to demonstrate and ensure enhanced CSR performance [20].

In order to have any significant effect, CSR has to be applied at every organizational level [21-24]. More research on how CSR can be usefully implemented, from an inside perspective, is therefore necessary [25]. CSR practice implies the implementation and integration of various effective management tools, such as management systems, as driving forces for sustainable development and value creation [26]. This is supported by Ranängen and Zobel, who claim that researchers seem to agree on the usefulness of established management systems in the development of CSR practice [8]. Management systems based on international standards are advantageous for implementing CSR $[23,27,28]$ and have been widely used in the Nordic mining industry [20]. The Nordic region is an area in Northern Europe that consists of the countries Denmark, Finland, Iceland, Norway, and Sweden. The established Nordic mining companies have implemented established management systems standards, especially in occupational health and safety (OHS) and the environment [20].

A management system's objective is to effectively organize, monitor, evaluate, and report CSR practices of sustainability criteria, such as the environment, OHS, and energy, with a clear focus on the strategic benefit, management commitment, life-cycle perspective, and actual benefit to society. At the planning stage, the environmental, energy, and OHS aspects are identified and documented. These aspects are then evaluated in order to identify the most significant, around which the rest of the management system is structured.

In the last decade, certifiable management systems have become more aligned and gained popularity globally [29], with the most known and widespread being quality management systems (QMS) based on ISO 9001, environmental management systems (EMS) based on ISO 14001, and occupational health and safety management systems (OHSMS) based on OHSAS 18001 [30-32]. Asif et al. and Rocha et al. highlight the advantages of integrating all sustainability aspects into a single sustainability management system (SMS) [2,28]. An integrated management system (IMS) avoids the duplication of tasks [29], is easier to manage and control [23], and can help companies to continuously improve their sustainability performance [27]. However, the management system approach needs to be developed by promoting incremental and radical improvements and encouraging greater cooperation 
with stakeholders [33]. Kemp et al. and Jørgensen support this view [34,35]. Kemp et al. argue that an external, stakeholder-driven focus and value-based approach would benefit SMSs [34]. Jørgensen claims that companies with certified management systems should strengthen their collaboration with stakeholders in order to create a more sustainable management system [35]. Further, a company's emphasis should be on 'doing the right things' before 'doing things right' [34]. 'Doing the right things' means value-based decision-making and a continuous dialogue with stakeholders [36].

Mele argues that stakeholder theory can be regarded as a CSR theory [6] and that it has been incorporated into CSR in the business literature to underpin corporate CSR practices [2]. Hörisch et al. state that stakeholder theory can be applied with advantage in CSR practice [37], although more applied research is needed to explore how it unfolds in that context [38]. Stakeholder management is about creating value through communication and interaction with stakeholders [39]. The integration of stakeholder management into SMS has been studied [21,23,24,40-42].

A literature search identified several academic papers describing stakeholder management in a management system approach. Asif et al. delineate a framework for the integration of CSR into business processes that emphasizes continuous improvements [21]. The framework is based on the 'top-down' and 'bottom-up' approaches to CSR. The top-down approach implies the integration of identified stakeholders' needs into existing management systems. The bottom-up approach signifies the interaction with less powerful stakeholders in the local community. The intentional consequence of the two approaches is to meet the needs of a broad range of stakeholders. Asif et al. state that important criteria for identifying stakeholders and stakeholder requirements are the power, urgency, and legitimacy of stakeholders [43], which are included in the step called 'systematization of stakeholder demands' [21].

Singh et al. present a framework in which the planning phase consists of 'stakeholder mapping' and 'stakeholder consultation' [42]. During the mapping, the stakeholders and their needs and expectations are identified. The consultation generates information that is relevant for the assessment of stakeholders' needs and expectations.

Azapagic argues that the implementation of SMS should be initiated with a 'stakeholder analysis' [24]. During the analysis, different stakeholders are listed and information about how stakeholders prioritize sustainability aspects are documented. Thus, the analysis assists the company in its decision-making about which sustainability aspects to target. Azapagic and Perdan advocate a corporate SMS for a more systematic approach to managing corporate sustainability beyond corporate boundaries [41]. The proposed system is compatible with general management system standards and consists of five steps: policy development, planning, implementation, communication, and performance review. Central to the system is the identification of stakeholders and key sustainability issues along the supply chains, the development of policies and actions that are needed to engage stakeholders and address their issues, the development of sustainability indicators and the measurement of sustainability performance to ensure continuous improvements, and the communication of progress to relevant stakeholders. Azapagic and Perdan recommend the well-documented stakeholder analysis [44] as a useful tool for the participation of stakeholders [41].

The framework for SMS presented by Castka et al. is based on the international standard ISO 9001 for quality management and has the purpose of transforming stakeholders' expectations in a company's operations [23]. The identification of key stakeholders is central and stakeholder salience is demonstrated by the same three attributes of power, legitimacy, and urgency [45].

Maas and Reniers propose a conceptual CSR framework, mainly on the basis of the umbrella guideline ISO 26000 [46]. In order to realize a structured CSR policy, they suggest that management should take care to ensure that (at least its most important) stakeholders are involved in the exercise of defining the organization's sustainable direction [40]. They further suggest that stakeholders should be identified and categorized using the matrix created by Mitchell et al. [43]. Nevertheless, it is often a question of conceptual SMS frameworks that do not describe how stakeholder management should be practiced, with the exception of, for example, studies presented by Ranängen and Ranängen $[47,48]$. 
Case study research is required in order to establish how these frameworks are interpreted in reality [21] and especially on the stakeholder assessment process and its transformation into CSR policies and objectives [23]. Therefore, the first proposition is that conceptual SMS frameworks for stakeholder management in a management system approach can be applied and improve CSR practice. However, an SMS includes significantly more aspects than those normally found in the IMS and traditional management system standards. Consequently, there are many aspects to be valued and prioritized. A materiality analysis can be applied to determine the relevance and significance of a sustainability aspect to an organization and its stakeholders $[49,50]$. In a materiality analysis, each sustainability aspect should be assessed in terms of "significance for stakeholders" and "significance for the organization" in order to determine materiality and priority. The assessment is then plotted on a two-axis chart to provide a picture of sustainability aspect priority. The aspects in the lower left-hand corner of the chart signify that they have relatively low importance for both the company and the stakeholders. Those in the upper left-hand corner represent aspects that have high value for stakeholders, yet low value for the company. The lower right-hand corner of the chart contains aspects that are very important for the company but not very important for stakeholders. Finally, in the upper right-hand corner are the aspects with high importance for both the company and its stakeholders and, consequently, those that should be given priority. Therefore, the second proposition is that the materiality analysis concept can be usefully applied to determine the relevance and significance of sustainability aspects in the planning step of SMS.

Hence, this study is set within the Nordic mining industry since it is practicing CSR and has integrated management systems in place. The study focuses on stakeholder management within a management system mindset in order to enhance social acceptance of mining. The first purpose is to describe a mining company's existing stakeholder management practice and to identify areas for improvement by using established stakeholder management models suggested in previous research in order to achieve an efficient and effective stakeholder management practice. The second purpose is to describe how conceptual SMS frameworks can be usefully applied in reality and, more specifically, whether and how stakeholder management models and the concept of materiality analysis can be useful for the planning step in an SMS for social acceptance.

Next, the methodology is outlined, followed by a presentation of the findings, which are then discussed and conclusions drawn.

\section{Methodology}

This study has an abductive approach and the chosen research method is a multiple case study. Case-study research is applicable if the purpose requires an in-depth description of a phenomenon [51]. The researcher is also able to investigate social phenomena in a real-life context [51,52]. A Nordic mining company, Company $\mathrm{X}$, was selected as a case company based on its communicated CSR performance, annual sustainability reporting, local context, and interesting competencies like metals recycling. The case study was performed at two levels: a strategic level represented by the management group at Company $X$ and an operational level represented by the management groups at Mine 1 and Mine 2. Consequently, the three management groups' stakeholder management practice constitutes the multiple case study. Further information about the respondents is presented in Section 2.2.

\subsection{The Sustainability Aspect Matrix}

Ranängen argues that the identification of stakeholders' needs and expectations would benefit from a more structured approach, because her study shows that for different reasons respondents can ignore or overlook important sustainability aspects [48]. Whitehead highlights different information sources that are useful for prioritizing aspects that take a diverse array of stakeholder perspectives into account [50]. Therefore, a sustainability aspect matrix was developed based on reviews of international CSR frameworks that are relevant for the mining industry in general $[20,53,54]$ and the CSR frameworks that are specifically implemented as a voluntary commitment by Company $X$ itself, as 
shown in Appendix A. These were identified by studying Company X's website and its annual reports from 2016, 2015, and 2014, and are especially important in that the long-term objective is to develop an SMS that supports all voluntary company commitments. The method for the development of the matrix was inspired by previous work presented by Ranängen and Lindman [20].

A literature review was conducted in order to identify the sustainability aspects that are relevant for the mining industry. A review is important for gaining an understanding of what has already been found, how it has been researched, and what the key issues are [55]. The search for literature was conducted in Scopus, Web of Science, and Google Scholar, and took place in the autumn of 2017. A list of literature titles and abstracts was printed out from each database/search and irrelevant literature and duplicates were discarded. Only journal articles were included, some of which were found through the snowball technique. The entire procedure resulted in 12 scientific papers, as shown in Appendix A.

The list of international CSR frameworks relevant for the mining industry in general and for the case company in particular, presented in Appendix A, was externally validated by the management groups consisting of positions with responsibility for sustainability.

\subsection{Interactive Workshops}

Case study data was collected via interactive workshops, as shown in Table 1 below. The purpose and the theoretical framework for conducting the workshops are further described in Table 2.

Table 1. Information about the workshops.

\begin{tabular}{cccccc}
\hline Action & Business unit & Level & Respondents & Date & Time (h) \\
\hline WS1 & Mine 1 & Operational & Management group-Mine 1 & 9 February 2018 & $\mathbf{2 . 5}$ \\
WS2 & Company X & Strategic & Management group Company X & 20 March 2018 & 4 \\
WS3 & Mine 2 & Operational & Management group-Mine 2 & 27 March 2018 \\
WS4 & Mine 1 & Operational & Management group-Mine 1 & 30 May 2018 & 1 \\
WS5 & Company X & Strategic & Management group Company X & 21 August 2018 & 1.5 \\
\hline
\end{tabular}

Table 2. The workshop steps, including purpose and theoretical framework.

\begin{tabular}{ccc}
\hline Workshop Steps & Theoretical Framework & Purpose with Data Collection \\
\hline 1. The stakeholder view & $\begin{array}{c}\text { Freeman (1984) } \\
\text { Ranängen (2017) }\end{array}$ & The identification of stakeholders. \\
\begin{tabular}{ccc} 
2. The two-tier stakeholder map & $\begin{array}{c}\text { Freeman et al. (2007) } \\
\text { Ranängen (2017) }\end{array}$ & $\begin{array}{c}\text { The division of stakeholders into primary and } \\
\text { secondary. Estimation of the level of communication } \\
\text { and the correlation between theory and practice. }\end{array}$ \\
\hline 3. Evaluating stakeholder-manager \\
relationships
\end{tabular} & $\begin{array}{c}\text { Mitchell et al. (1997) } \\
\text { Ranängen (2017) }\end{array}$ & $\begin{array}{c}\text { The division of stakeholders into latent, expecting, } \\
\text { and definitive stakeholders. }\end{array}$ \\
\hline 4. Assessment of sustainability aspects & Beske et al. (2019) \\
Whitehead (2017) & $\begin{array}{c}\text { To prioritize the sustainability aspects in the } \\
\text { sustainability aspect matrix based on } \\
\text { business success. }\end{array}$ \\
\hline
\end{tabular}

Interactive research can be used for the joint learning of researchers and practitioners and is used to bring theory to practice [56]. The researcher's role is to transfer knowledge and to simplify and translate theory so that the practitioners can easily assimilate it, while researchers gain important knowledge about how theories can be perceived and interpreted by practitioners [57]. During the workshops, the focus was on the theoretical framework presented in Table 2 and how the management groups at Company X, Mine 1, and Mine 2 received and applied it. One of the researchers led the workshops by presenting the theoretical framework that was going to be applied, describing the workflow, and acting as facilitator for the workshop steps 1-4. The other researcher's responsibility was to document and record the results. The workshops were carried out in a conference room at Company X, Mine 1, and Mine 2. More specifically, the management groups proposed stakeholder groups that were then written down on post-it notes and attached to a whiteboard with the business unit in the middle. Then, the stakeholder groups were evaluated into primary and secondary [39] by moving the post-it notes around on the whiteboard. The notes with 'secondary stakeholders' were 
moved further out and the 'primary stakeholders' closer to the middle. The next step was to estimate the level of interaction between the business unit and the stakeholder groups in order to evaluate how well the produced 'two-tier stakeholder map' correlated with the actual stakeholder interaction. The respondents drew arrows on the whiteboard between the business unit and the stakeholder groups. Thick arrows represented a lot of time and energy being put into interaction and the thin arrows little time and energy. The business units were also asked to define the interaction. A two-way arrow was used to show the communication interactions, i.e., a dialogue, and a one-way arrow for the transfer of information in any direction.

The next step was to estimate "who and what really counts" [43]. Here, the previously identified stakeholder groups were evaluated based on the three attributes of power, legitimacy, and urgency. All these steps were displayed on whiteboards and documented by taking photographs of the result, which were later saved in a database together with the recordings of the workshops. The workshops ended with an assessment of the importance of the sustainability aspects in the sustainability aspect matrix for business success on a scale from 1 to 5 , where 1 was 'not important', 2 'less important', 3 'important', 4 'fairly important', and 5 'very important'. For this step, an excel sheet was prepared in advance and the assessment was completed together. The excel sheet was saved together with the pictures and recordings in the database. Opportunities for reflection were created during the interactive workshops by setting aside time for questions and discussion, but also by challenging the respondents with more profound questions about the implication of the theories presented.

\subsection{Structured Interviews and Stakeholder Surveys}

Case study data were collected by means of structured interviews and a survey. Company X, Mine 1, and Mine 2 provided a list with the contact information for the stakeholders in each stakeholder group identified during the workshop. The interviews were conducted by telephone from May to September 2018. Citizens in the local community received information about the ongoing research project via local newspapers and advertisement supplements with a link to the survey. The employees were emailed in June 2018 with information about the project and a link to the survey. The remainder of the stakeholders received the survey by email. The purpose of the interviews and surveys was to determine the 'significance to stakeholders', i.e., how important the sustainability aspects in the sustainability aspect matrix were for the stakeholders. The stakeholders were asked to value the importance on a scale from 1 to 5 , where 1 was 'not important', 2 'less important', 3 'important', 4 'fairly important', and 5 'very important'.

\subsection{Determination of Materiality}

The final case study step was inspired by [58] and [50] materiality analysis methodology for prioritizing sustainability aspects. The sustainability aspects' 'importance for business success' were plotted on the x-axis, and the 'importance to stakeholders' on the y-axis. Thus, in the final step, the data from the reviews, workshops, interviews, and surveys were compiled into a materiality analysis and a prioritization of sustainability aspects identified.

\section{Results}

The results from the nine case study steps are presented below.

\subsection{The Sustainability Aspect Matrix}

The international CSR frameworks and academic papers presented in Appendix A were reviewed and the sustainability aspects in them identified. Some of the documents focus on one single subject, for example ISO 14001 and the UN Universal Declaration of Human Rights. Others embrace several subjects, such as the UN's Global Compact, ISO 26000, or the Global Reporting Initiative (GRI) framework. The identified aspects were divided into the main subjects of corporate governance, economic aspects, fair operating practices, human rights, labor practices, society, product responsibility, 
and the environment, and the identified sustainability aspects were listed and described under each main subject, as shown in columns 1 and 2 in Appendix B. The matrix was further used as a basis for the stakeholder interviews and survey and the determination of materiality. The result from the multiple case study is presented in the next section.

\subsection{The Company X Case}

The first task was to identify the company stakeholders [44]. Suggestions for stakeholders were rapidly delivered and were often related to the respondents' own responsibilities. This resulted in twenty stakeholder groups, as shown in Figure 1. Business partners include both customers and suppliers, while regulators are authorities such as the Swedish Environmental Protection Agency (SEPA) and the County Administrative Board. The local community generated some discussion and the respondents argued about the different levels. They talked about the society at large, which included the environment, the society that can be affected by bad publicity, and a more global view of the market they were producing metals for. Landowners who were affected by noise, dust, and so on were also identified. Neighbors are the people living in the area and the local community is represented by the municipality. In the second step, the stakeholder groups were divided into primary and secondary [39] by the management group, as shown in Figure 1.

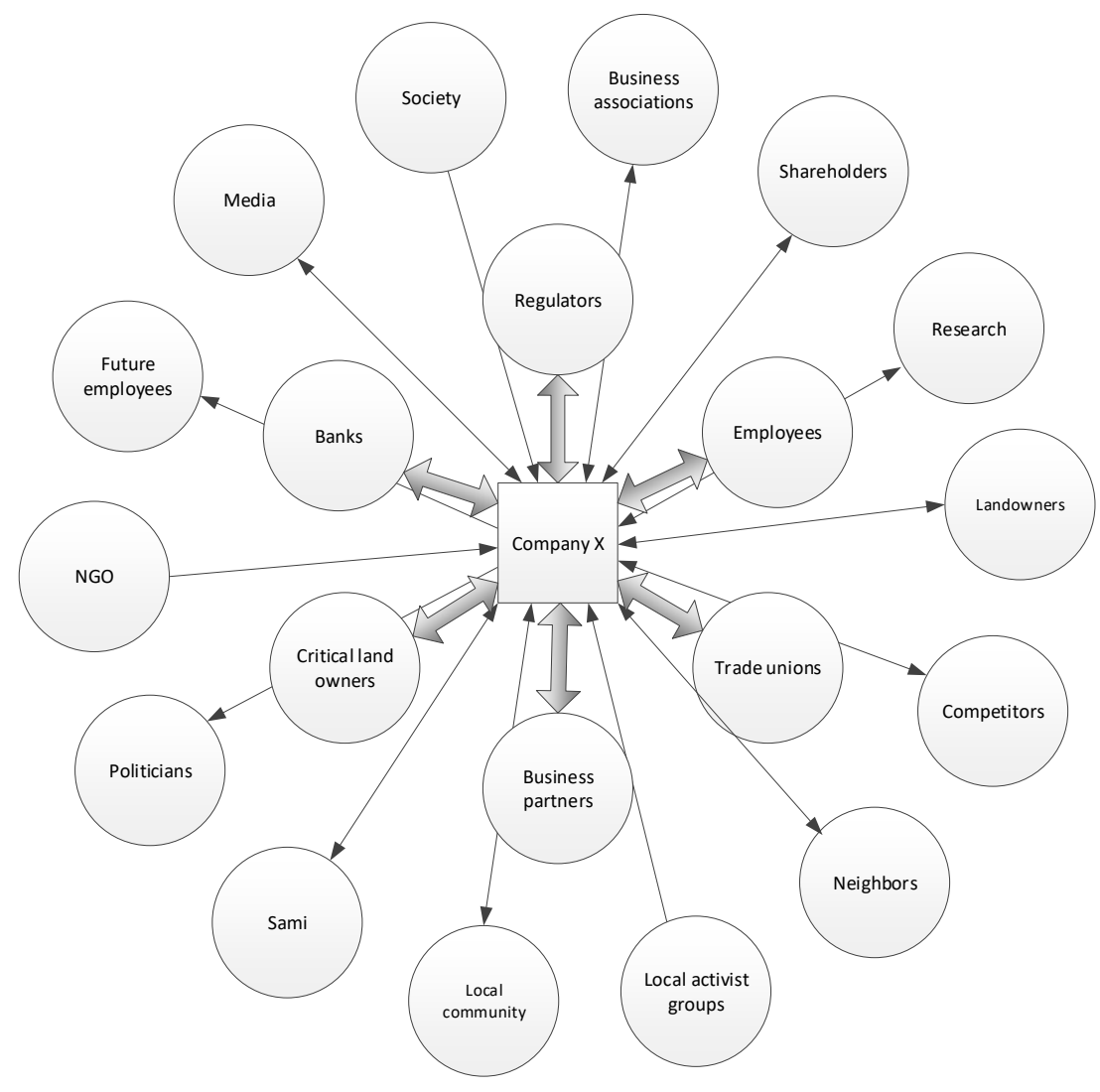

Figure 1. Company X's two-tier stakeholder map based on Freeman et al. [39] with an estimation of the communication with stakeholder groups.

Figure 1 shows that Company $\mathrm{X}$ evaluated regulators, employees, trade unions, business partners, critical landowners, and banks as primary stakeholders. The rest are seen as secondary stakeholders. The level of interaction between Company $X$ and the identified stakeholder groups was then estimated in order to determine how well Company X's two-tier stakeholder map correlated with the actual stakeholder interaction. The management group drew thinner arrows to the stakeholder groups in the outer circle and thicker arrows to those in the inner circle. This indicates that Company $\mathrm{X}$ put a lot of 
time and effort into interacting with its primary stakeholders and less with the secondary. The two-way arrows to the primary stakeholders indicate that the interaction is a matter of communication. The results are presented in Figure 1.

We then estimated "who and what really counts" [43]. The stakeholder groups were evaluated based on the three relationship attributes of power, legitimacy, and urgency. The stakeholder group that received the most attention was employees. They found both the models easy to work with and thought that if a three-dimensional scale had been used in the first one, they would perhaps have got the same result. However, if they had a choice, they would go for the second one, because it was perceived as being more objective.

The evaluation divided the stakeholder groups into different stakeholder classes [43], as shown in Table 3 and Figure 2. The table shows that banks, business partners, regulators, and trade unions are classified as definitive stakeholders, i.e., the most important, with future employees and competitors being regarded as non-stakeholders when applying theory.

Table 3. The evaluation of stakeholder groups based on Mitchell et al. [43].

\begin{tabular}{|c|c|c|}
\hline Latent Stakeholders & Dormant Stakeholders (P) & Shareholders \\
\hline & & Politicians \\
\hline & Discretionary stakeholders (L) & Landowners \\
\hline & & Society \\
\hline & & Research \\
\hline & & NGO \\
\hline & & Local community \\
\hline & & Local activist groups \\
\hline \multirow[t]{6}{*}{ Expectant stakeholders } & Dominant stakeholder $(\mathrm{P}+\mathrm{L})$ & Critical landowners \\
\hline & & Business associations \\
\hline & Dependent stakeholder $(\mathrm{L}+\mathrm{U})$ & Employees \\
\hline & & Media \\
\hline & & Neighbors \\
\hline & & Sami \\
\hline \multirow[t]{4}{*}{ Definitive stakeholders } & Definitive stakeholder $(\mathrm{P}+\mathrm{L}+\mathrm{U})$ & Banks \\
\hline & & Business partners \\
\hline & & Regulators \\
\hline & & Trade unions \\
\hline \multirow[t]{2}{*}{ Non-stakeholders } & & Future employees \\
\hline & & Competitors \\
\hline
\end{tabular}

The importance of stakeholders' needs and what they expect from the company was estimated by the importance of the business success aspect $[50,58]$. The main subjects of ethical conduct, respect for human rights, and the environment (in that order) are of greatest importance. Overall, Company $X$ evaluates societal sustainability rather low, with the exception of health impacts and geotechnical hazards and accidents. Company $X$ also evaluates the economic aspects rather low. The result is presented in column 3 (Company X) in Appendix B.

The stakeholder survey and interviews target the listed stakeholders identified by the management groups, as shown in Figure 2, Figure 5, and Figure 8. In total, 114 responses were received. After deleting five responses (blanks and when the respondent had stopped in the middle of the survey), 109 responses remained. For the demographics of the respondents, see Table 4. 


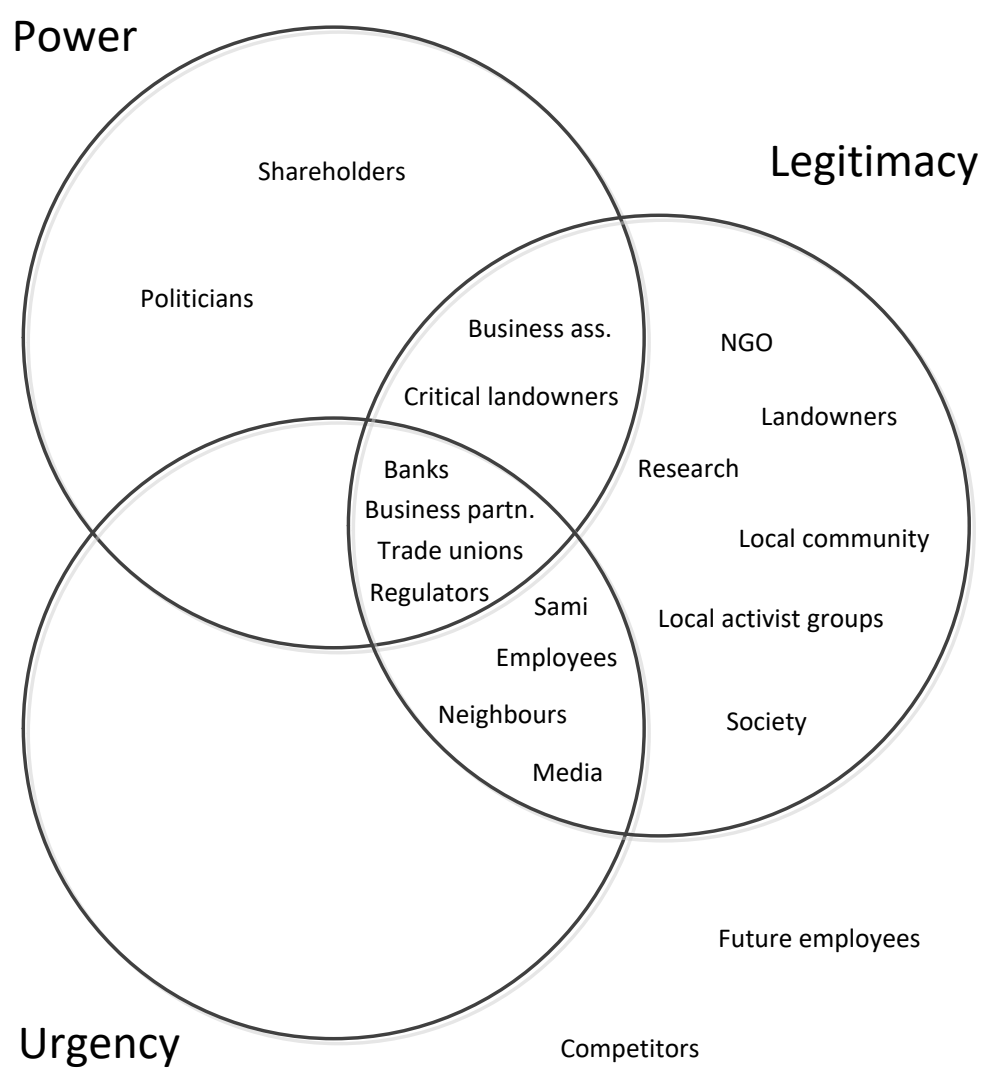

Figure 2. The evaluation of stakeholder groups based on Mitchell et al. [43].

Table 4. Demographics of the respondents.

\begin{tabular}{cccc}
\hline \multicolumn{2}{c}{ Respondents by Country } & Respondents by Affiliation & \\
\hline Country 1 & 63 & Municipality citizens & 16 \\
\hline Country 2 & 46 & Employees & 45 \\
\hline Number & 109 & Other stakeholders & 48 \\
\hline
\end{tabular}

The stakeholder groups that remained after excluding 'municipality citizens' and 'employees' are called 'other stakeholders'. The response rate for 'other stakeholders' was $41 \%$. We assume that the response rate is low for 'municipality citizens' and 'employees'. This cannot be estimated, because the number of staff varied over the time period and the number of citizens who saw the advert in the newspaper and were able to respond to the survey are unknown.

We moved the data from the survey and interviews, as shown in column 4 (Mean) in Appendix B, into one data set for several reasons. One was due to the fact that the business units in a number of cases identified the same stakeholders, and we only wanted to contact them once, and another because the responses from stakeholders in many of the stakeholder groups were too few to draw statistically relevant and significant conclusions.

In general, all the sustainability aspects are regarded as important to the stakeholders $(\geq 3.1)$, see column 4 in Appendix B. Very important aspects $(\geq 4.7)$ are found in the main subject of labor practice (equality, remuneration), ethical conduct (anti-corruption), human rights (child labor, non-discrimination, civil and political rights, forced or compulsory labor), the environment (waste management, resource use of water, toxic and hazardous chemicals and materials, effluents to water), society (geotechnical hazards and accidents), and corporate governance (respect for international norms of behavior, respect for the rule of law). None of the economic aspects were regarded as very important. 
A materiality analysis, as shown in Figure 3, was developed based on the result from Company X, its estimated significance of stakeholders' needs and expectations for business success [50], and the results from the stakeholder survey and the interviews. It is clear that Company $X$ and its stakeholders evaluated the aspects similarly, as most of the aspects are found in the upper right-hand corner. Company $X$ regards technology development and access, economic, social and culture rights, equality in society, culture and art, community safety, and the recycling of metals as 'not relevant', whereas the stakeholders regard these aspects as important.

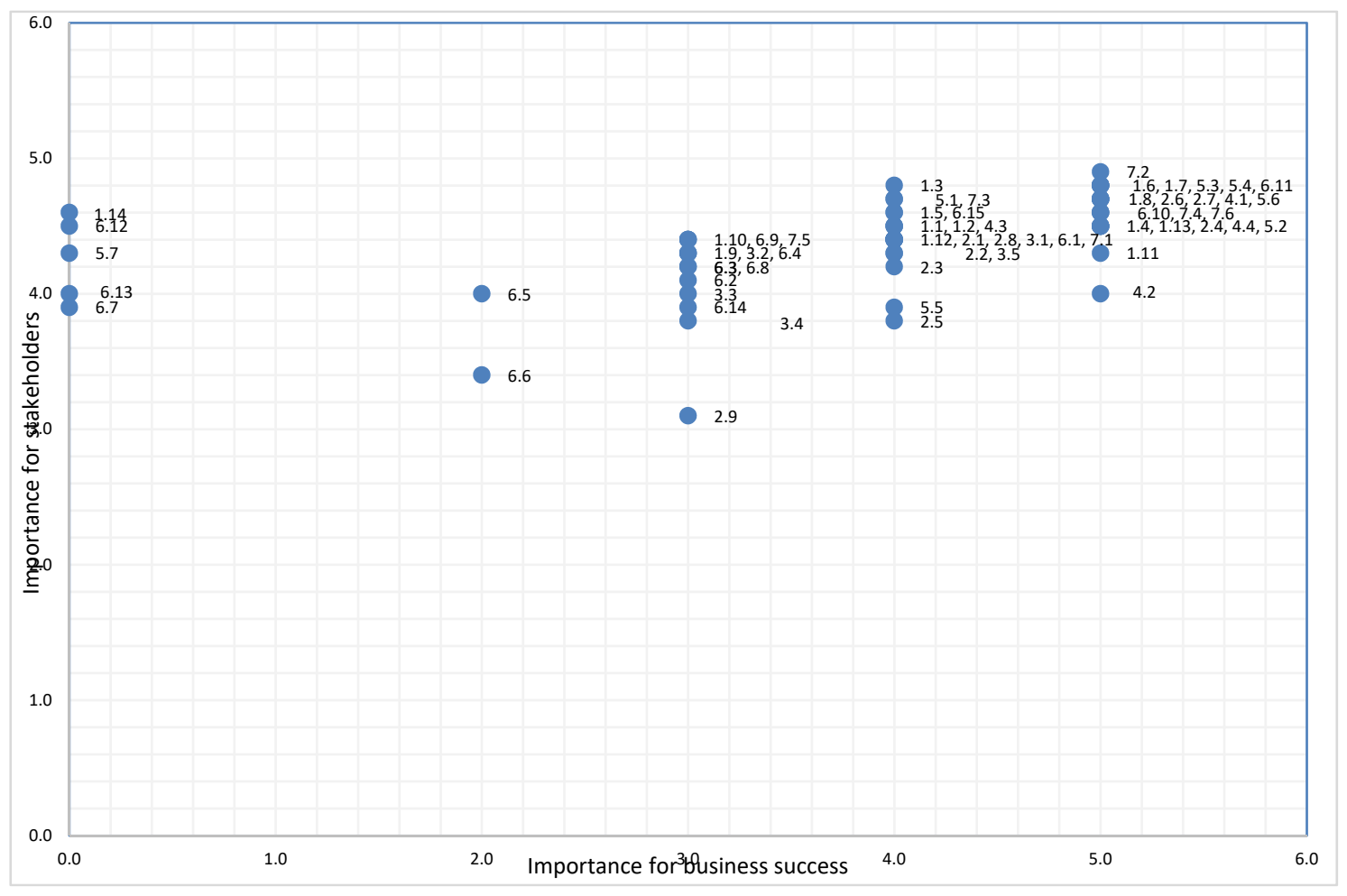

Figure 3. The materiality analysis for Company $X$.

\subsection{The Mine 1 Case}

This section presents the results from the Mine 1 case. The first task was to identify the company stakeholders [44]. Neighbors were the first stakeholder group to be mentioned and were defined as people who are directly affected by the mining, for example, when the operations spread over new land areas and people have to move or are in different ways affected by blasting. People living in the municipality who are not directly affected by the mining are defined as municipality citizens. The authorities are local, regional, and national and some examples are the local council, the County Administration Board, the Agency for Marine and Water Management, the Environmental Protection Agency, the Mining Inspectorate etc. Suppliers include consultants and contractors. Mine 1 only has one customer, a specific smelter. Local associations are especially represented by sports associations and others with an interest in the company. Owners are the shareholders that are represented by the stakeholder group Board of Directors, and the financial analysists are those who advise shareholders when to sell or buy shares in the company. The media includes local, industry, and financial newspapers as well as TV channels. Infrastructure consists of roads, railways, and the local airport. The respondents also discussed 'consumers' of metals but decided that this was the group level's stakeholder. The stakeholder groups were quickly suggested and often related to the managers' own responsibilities. This resulted in twenty-three stakeholder groups, as shown in Figure 4.

In the second step, the management group divided the stakeholder groups into primary and secondary stakeholders [39], as shown in Figure 4. Mine 1 evaluates owners, Company X's management, 
employees, customers, suppliers, reindeer herding, neighbors, trade unions, and authorities as primary stakeholders. The rest are seen as secondary stakeholders. However, it was considered that this division could change over time.

Next, in order to examine how well Mine 1's two-tier stakeholder map correlated with the actual interaction, the level of interaction between the company and the identified stakeholder groups was discussed. The result is presented in Figure 4.

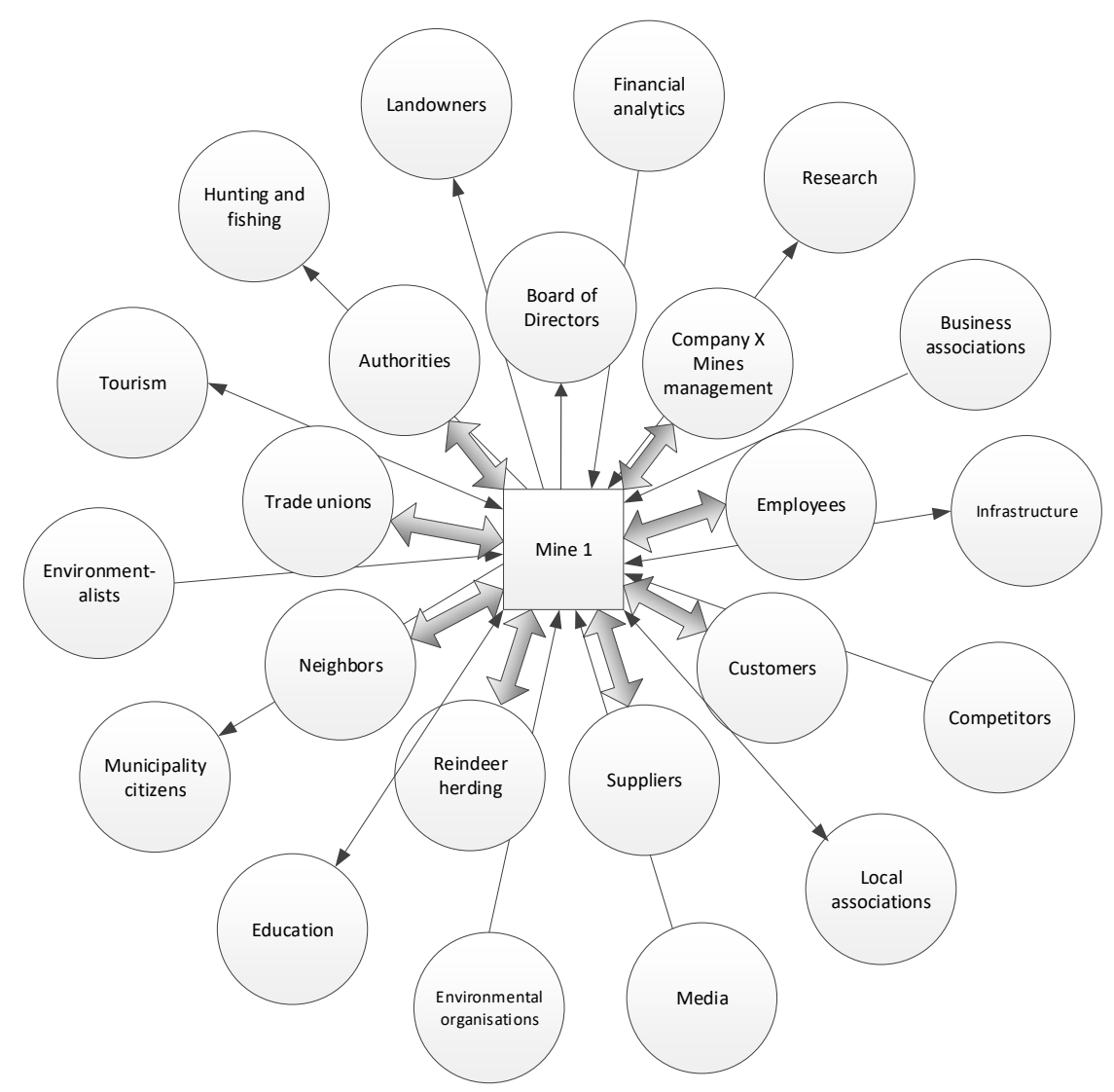

Figure 4. The Mine 1 two-tier stakeholder map based on Freeman et al. [39] with an estimation of interaction with stakeholder groups.

Overall, the management group drew thinner arrows to the stakeholder groups in the outer circle and thicker ones to those in the inner circle, with the exception of the Board of Directors. This indicates that Mine 1 put a lot of time and effort into the interaction with its primary stakeholders and less with the secondary. The two-way arrows to the primary stakeholders indicate that the interaction is a matter of communication. From this, we understand that Mine 1 has extensive communication with its primary stakeholders, as the theory claims. The interaction with the Board of Directors is perceived as low. The third step was to evaluate the stakeholders. The evaluation is presented in Table 5 . The respondents found it hard to evaluate the legitimacy of the stakeholder relationship with Mine 1, especially for the stakeholder groups of competitors, financial analysists, and environmentalists. 
Table 5. Mine 1's evaluation of stakeholder groups based on Mitchell et al. [43].

\begin{tabular}{|c|c|c|}
\hline \multirow[t]{11}{*}{ Latent Stakeholders } & Discretionary Stakeholder & Municipality Citizens \\
\hline & & Hunting and fishing \\
\hline & & Tourism \\
\hline & & Competitors \\
\hline & & Landowners \\
\hline & & Business associations \\
\hline & & Research \\
\hline & & Local associations \\
\hline & & Education \\
\hline & & Financial analytics \\
\hline & & Environmental organizations \\
\hline \multirow[t]{5}{*}{ Expectant stakeholders } & Dominant stakeholder & Board of Directors \\
\hline & & Infrastructure \\
\hline & Dependent stakeholder & Neighbors \\
\hline & & Reindeer herding \\
\hline & & Media \\
\hline \multirow[t]{6}{*}{ Definitive stakeholders } & Definitive stakeholder & Authority \\
\hline & & Suppliers \\
\hline & & Customers \\
\hline & & Employees \\
\hline & & Trade unions \\
\hline & & Company X's management \\
\hline
\end{tabular}

The evaluation divided the stakeholder groups into different stakeholder classes [43], as shown in Table 5 and Figure 5. The table shows that the authority, suppliers, customers, employees, trade unions, and Company $X^{\prime}$ 's management are seen as definitive stakeholders, i.e., the most important.

In sum, the two models resulted in almost the same result. The workshop ended with a discussion about whether the management group thought that it could use any of these models for its strategic sustainability work. The answer was "Absolutely". However, the managers thought that it was important to have a fixed time perspective when evaluating the stakeholders, otherwise the result may differ. They also highlighted the problem that if social acceptance was required, these models would not help.

The results of the estimation of the significance of stakeholders' needs and expectations are presented in column 3 (Mine 1) in Appendix B. For Mine 1, the subjects ethical conduct, the environment, and corporate governance are the most important. In general, Mine 1 evaluated sustainability aspects in human rights and society as less important for business success, with the exception of the aspects of resettlement of community/households, health impacts, and geotechnical hazards and accidents. The result from the stakeholder interviews and survey is described in detail in Section 3.2 and is presented in column 4 (Mean) in Appendix B.

A materiality analysis was developed based on the result from Mine 1, and the results from the stakeholder interviews and survey can be seen in Figure 6. 


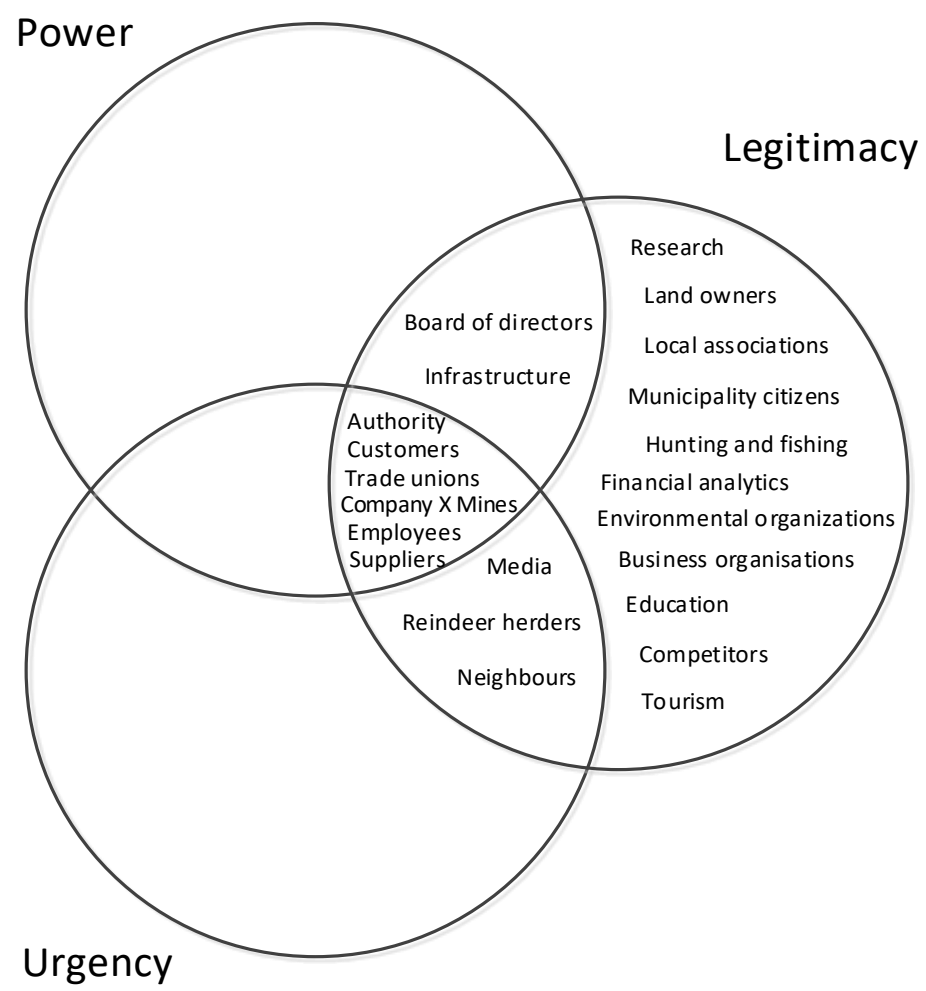

Figure 5. Mine 1's evaluation of stakeholder groups based on Mitchell et al. [43].

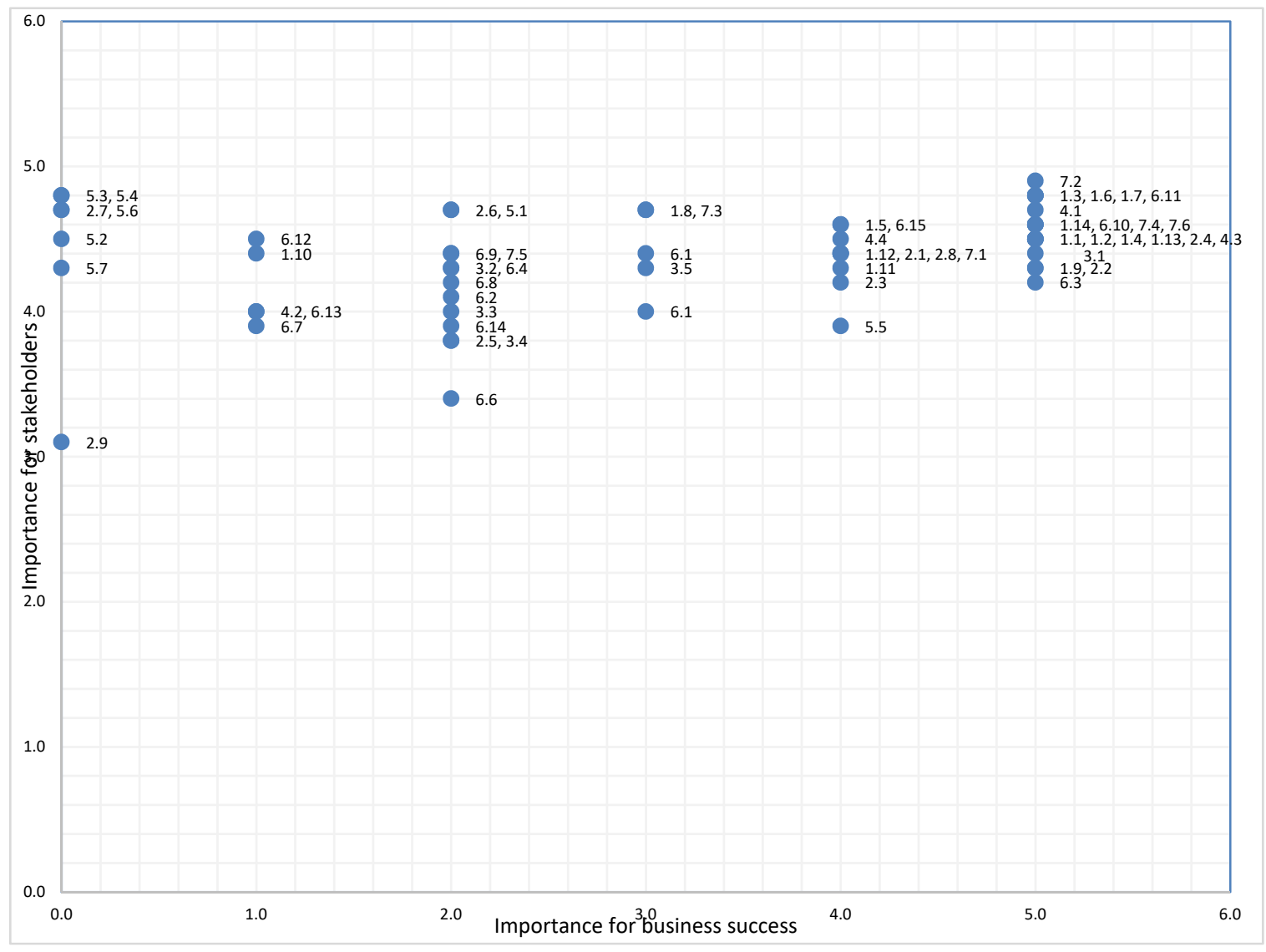

Figure 6. The materiality analysis for Mine 1. 


\subsection{The Mine 2 Case}

The respondents at Mine 2 were asked to identify the company stakeholders [44]. The suggestions were delivered rapidly and were often connected to the managers' own responsibilities. Neighbors are villagers, municipality citizens, and local companies. Logistics include roads and a nearby port. Owners are the shareholders. This resulted in twenty-three stakeholder groups, as shown in Figure 7. The management groups then divided the stakeholder groups into primary and secondary [39], which again can be seen in Figure 7. Mine 2 put owners, media, employees, customers, suppliers, contractors, Company $\mathrm{X}$ mines, municipality, and authority as primary stakeholders. The rest are seen as secondary stakeholders, as shown in Figure 7. The evaluation of the media as a primary stakeholder was justified by the interest the media has for the business. Mine 2 put all the community stakeholders, apart from municipality, as secondary stakeholders.

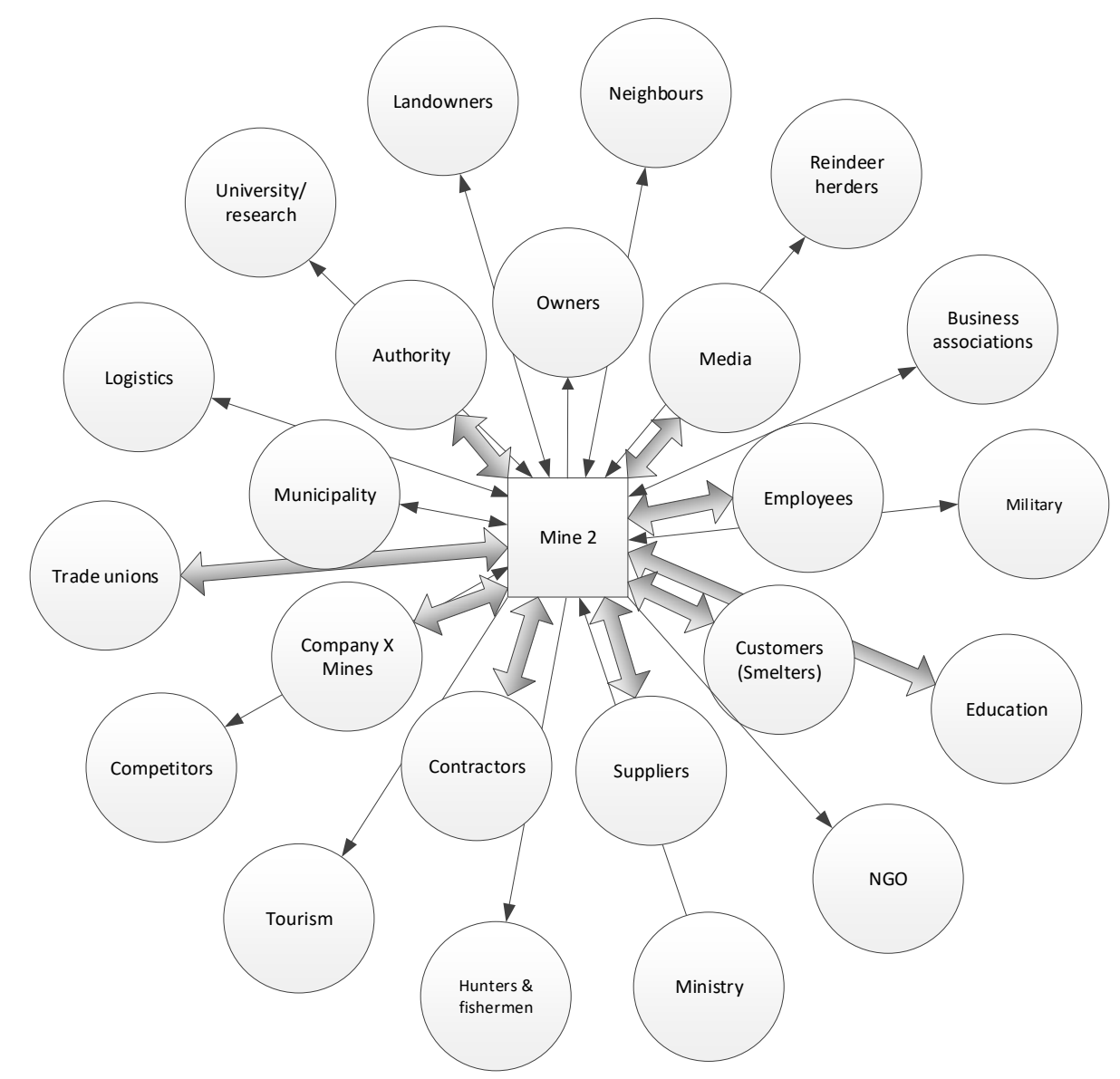

Figure 7. Mine 2's two-tier stakeholder map based on Freeman et al. [39] with an estimation of interaction with stakeholder groups.

The level of interaction between Mine 2 and the identified stakeholder groups was discussed in order to estimate how well Mine 2's two-tier stakeholder map correlated with the actual interaction. This was done rather quickly, without any divergent opinions, and the result is presented in Figure 7. In general, the managers drew thinner arrows to the stakeholder groups in the outer circle and thicker ones to the inner circle, with two exceptions. A thin arrow represented little communication with owners and municipality, despite these stakeholder groups being seen as primary stakeholders.

The fourth step was to evaluate the stakeholders and the result is presented in Table 6 and Figure 8. The table shows that customers, ministries, non-governmental organizations (NGOs), authorities, contractors, trade unions, Company $\mathrm{X}$, employees, and the media are classified as definitive 
stakeholders, i.e., the most important, while tourism, education, and the military are regarded as non-stakeholders according to theory.

Table 6. Mine 2's evaluation of stakeholder groups based on Mitchell et al. [43].

\begin{tabular}{|c|c|c|}
\hline Latent Stakeholders & Discretionary Stakeholder (L) & Business Associations \\
\hline & & Reindeer herders \\
\hline & & Landowners \\
\hline & & University/research \\
\hline & & Competitors \\
\hline & & Municipality \\
\hline & & Hunters/fishery \\
\hline & & Neighbors \\
\hline \multirow[t]{3}{*}{ Expectant stakeholders } & Dominant stakeholder $(\mathrm{P}+\mathrm{L})$ & Owners \\
\hline & Dependent stakeholder $(\mathrm{L}+\mathrm{U})$ & Suppliers \\
\hline & & Logistics \\
\hline \multirow[t]{9}{*}{ Definitive stakeholders } & Definitive stakeholder $(\mathrm{P}+\mathrm{L}+\mathrm{U})$ & Customers \\
\hline & & Ministries \\
\hline & & NGO \\
\hline & & Authorities \\
\hline & & Contractors \\
\hline & & Trade unions \\
\hline & & Company X Mines \\
\hline & & Employees \\
\hline & & Media \\
\hline \multirow[t]{3}{*}{ Non-stakeholder } & & Tourism \\
\hline & & Education \\
\hline & & Military \\
\hline
\end{tabular}

In the second model, owners and suppliers were regarded as expectant stakeholders (less important). The applicability of the two models was discussed and the respondents summarized by saying that it made sense to do both, but that some preferred the last one.

For the results from the estimation of the significance of stakeholders' needs and expectations, see column 3 (Mine 2) in Appendix B. For Mine 2, the main subjects of corporate governance, labor practices, ethical conduct, and the environment (in that order) are the most important. The results from the stakeholder interviews and survey are described in detail in Section 3.2 and are presented in column 4 (Mean) in Appendix B. Based on these results, a materiality analysis was developed, as shown in Figure 9. Mine 2's materiality analysis presents more aspects in the upper left-hand corner compared to that of Company X, but fewer than in Mine 1's. 


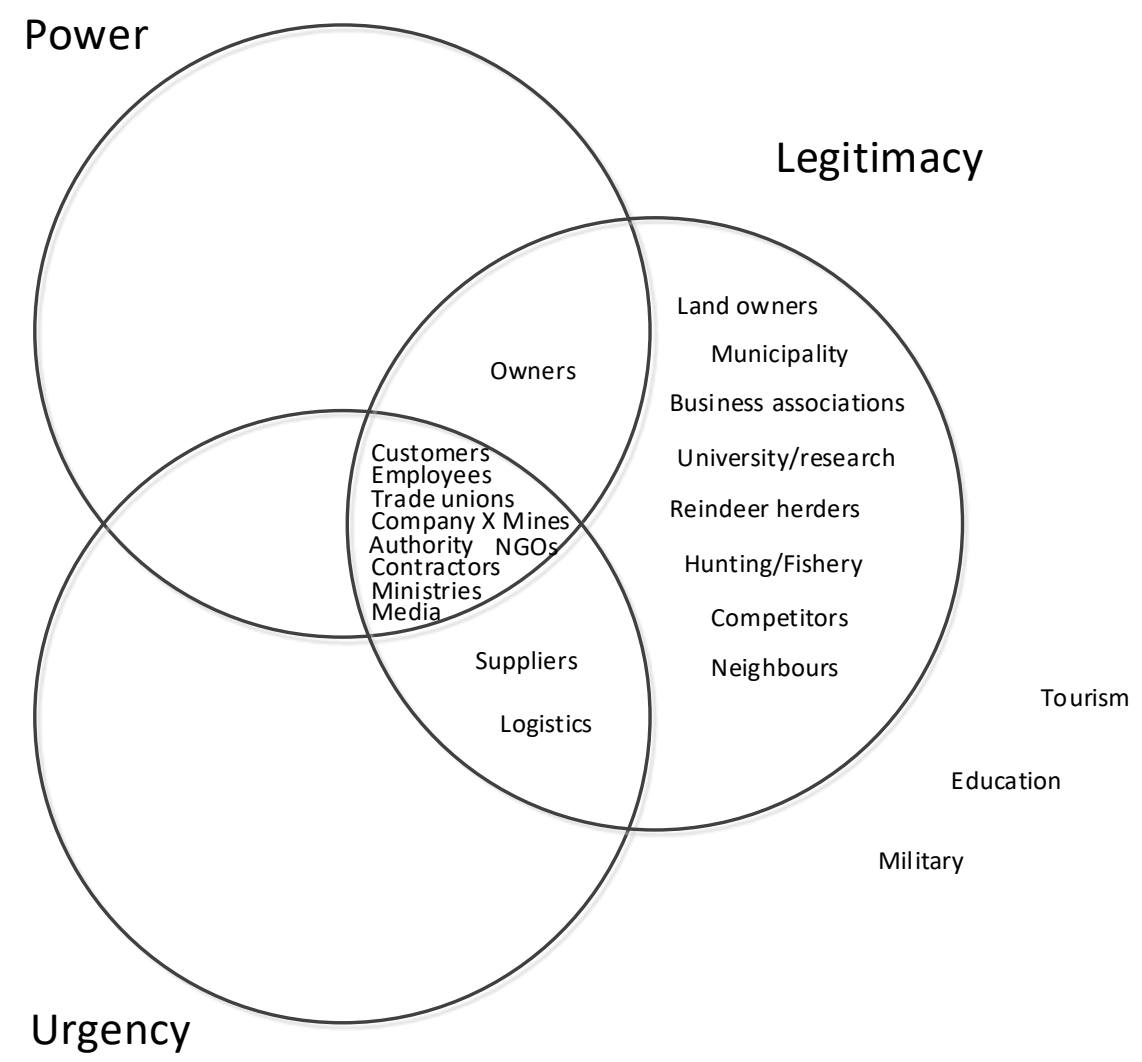

Figure 8. Mine 2's evaluation of stakeholder groups based on Mitchell et al. [43].

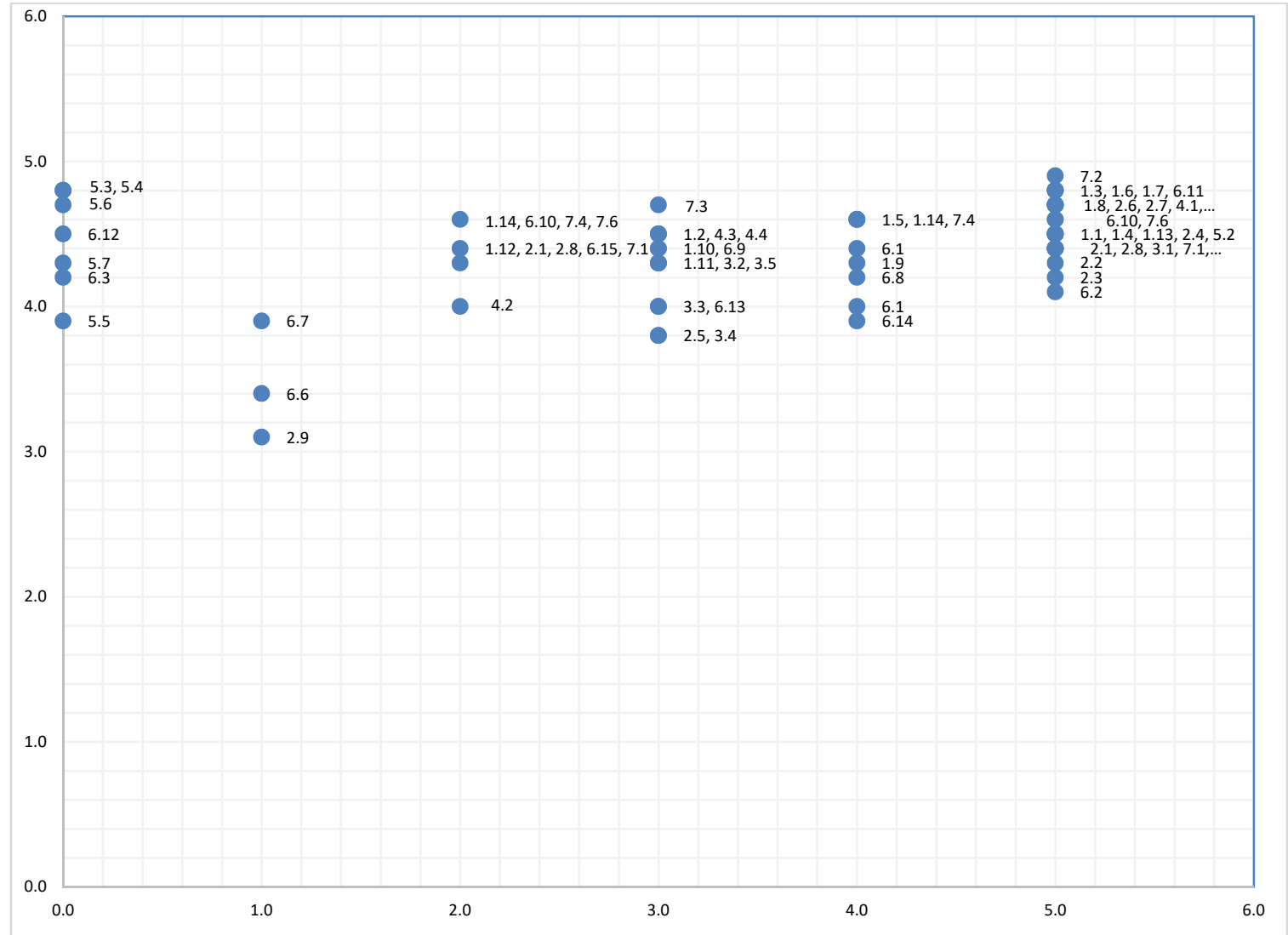

Figure 9. The materiality analysis for Mine 2. 


\section{Discussion}

The purpose of this study has been to describe a mining company's existing stakeholder management practice and to identify areas for improvement by using established stakeholder management models in order to achieve an efficient and effective stakeholder management practice.

The result shows that in all three cases, more detailed stakeholder maps were generated during the workshops than the theory suggests. Company $\mathrm{X}$ has in some cases grouped the stakeholders into business partners, which includes both customers and suppliers. In many cases it is the opposite. For example, community is divided into several stakeholder groups, such as society, local community, neighbors, critical landowners, landowners, and so on. Special interest group (SIG) is divided into NGOs, local activist groups, trade unions etc. Mine 1 has also detailed the stakeholder groups 'SIG' and 'community'. SIG has been substituted for environmental organizations, trade unions, business associations etc. Community has been replaced by neighbors, reindeer herding, municipality citizens, infrastructure, landowners, and education. Mine 2 has expanded the two stakeholder groups SIG and 'community'. SIG has been substituted by NGOs, business organizations, and trade unions. Community has been replaced by tourism, education, military, reindeer herders, landowners, university/research, logistics, and hunters/fishery. This increased level of detail can be explained by the fact that we are now studying stakeholder management at a local level, where the positive, but perhaps above all the negative, aspects of mining are the most significant. This is expected when moving from theory to practice. However, the strategic and operational company levels have in many cases suggested the same stakeholder groups. For example, Company $\mathrm{X}$ defined landowners, neighbors, local community, and local activist groups as stakeholder groups, just as Mine 1 and Mine 2 did. Another interesting finding is that Mine 1 defined Board of Directors (the level above Company X) as a stakeholder; one that Company X missed. In order to improve the mining company's existing stakeholder management practice, it should carefully consider which stakeholders should be managed at the respective business level in order to create a more structured and efficient stakeholder management.

The management groups divided the stakeholder groups into primary and secondary [39]. Company $\mathrm{X}$ evaluated regulators, employees, trade unions, business partners, critical landowners, and banks as primary stakeholders. The rest are seen as secondary stakeholders, as shown in Figure 1. In compliance with the theory, business partners, employees, and banks are seen as primary stakeholders. However, in theory, community is also seen as a primary stakeholder, but Company $\mathrm{X}$ has evaluated most of the community stakeholders as secondary. Another difference is that, in theory, trade unions are seen as secondary stakeholders as a part of SIG. Mine 1 evaluated owners, Company X's management, employees, customers, suppliers, reindeer herding, neighbors, trade unions, and authorities as primary stakeholders. The rest were seen as secondary stakeholders, as shown in Figure 4. According to theory, the community is regarded as a primary stakeholder. Mine 1 has two community stakeholders as primary stakeholders-neighbors and reindeer herding — with the rest being seen as secondary stakeholders (neighbors, municipality citizens, infrastructure, landowners, and education). However, it was considered that this division could change over time. Instead, Mine 1 upgraded trade unions and authority as primary stakeholders. The fact that Mine 1 put financial analysists as a secondary stakeholder (primary stakeholder in theory) can be explained by the level we are studying. This is of more importance for the strategic level (Company X). That both Company $X$ and Mine 1 have upgraded the significance/importance of trade unions and authority/regulators as primary stakeholders can be explained by the Nordic context, where trade unions are the result of the great influence of the labor movement and where compliance with laws and regulations is important. Mine 2 put owners, the media, employees, customers, suppliers, contractors, Company $\mathrm{X}$ mines, municipality, and authority as primary stakeholders. The rest are seen as secondary stakeholders, as shown in Figure 7. Compared to theory [39], Mine 2 put authorities and media as primary stakeholders, whereas in theory these are seen as secondary. The evaluation of the media as a primary stakeholder was justified by the great interest the media has for the business. Mine 2 put all the community stakeholders, apart from municipality, as secondary stakeholders, whereas they are seen as primary stakeholders in theory. 
In all three cases, and especially at the operational level, the stakeholder group 'community' was divided into several stakeholder groups, such as neighbors, reindeer herding, municipality citizens, landowners, hunting and fishing, tourism etc. As already indicated, this is expected when theory is applied in practice. This fact indicates that the company is very aware of the stakeholders in the local community, which is a necessary condition for obtaining social acceptance for its activities. The mining industry has experienced increased stakeholder pressure [6,7] and often communicates and reports on its social responsibility [59]. However, most of the community stakeholders are valued as secondary stakeholders [39], or as latent and expectant stakeholders [43] by the management groups. Could it be that SLO and social acceptance are not prerequisites in a Nordic perspective? Or, can it be explained by the Nordic permit process, where mining companies apply for permits using environmental and/or social impact assessments, rather than addressing the needs and expectations of the community and its stakeholders? Notwithstanding, the mining company should reflect on its evaluation of the sustainability aspects that are important for stakeholders if it wants to gain social acceptance for its mining activities in the local community.

The level of interaction with stakeholders was evaluated in the second case study step. The findings show that all three management groups estimated the communication with primary stakeholders as extensive. The interaction with the secondary stakeholders was found to be less extensive. Especially at the operational level, it was a matter of disseminating information rather than two-way communication. This is in accordance with the theories we tested. However, an inclusive and meaningful engagement with stakeholders can credit the SLO [60], in that dialogue with community stakeholders will lead to stronger relationships, increased perceptions of procedural fairness and trust, which in turn leads to social acceptance of the mining [19]. Hence, for business organizations needing a social license to operate, our recommendation is to evaluate the interaction with stakeholders, and if the interaction with community stakeholders is perceived as scarce, develop new strategies for communication with the community stakeholder groups. Next, we estimated "who and what really counts" [43], where the stakeholder groups were evaluated based on the three relationship attributes of power, legitimacy, and urgency. In sum, the results from the two models are alike. However, this second model gives a more detailed and profound result.

The purpose of this study has also been to describe how conceptual SMS frameworks could be usefully applied in practice and, more specifically, whether and how the stakeholder management models and the concept materiality analysis could be advantageous for the planning step in an SMS for social acceptance. Based on the findings, we believe that the SMS framework presented by Asif et al. [21] fits well in this context. Through its management system approach, the company can be confident that it will continue to manage its sustainability responsibilities in a systematic manner [61] and 'do things right' [34]. The top-down approach emphasizes the identification of stakeholder needs and expectations and the integration of the same into traditional management system thinking. This is where most of the primary stakeholders' [39] or the definitive stakeholders' [43] needs and expectations identified in the case study would be translated into strategic CSR goals and business processes. The bottom-up approach provides a systematic approach, where the company can interact with the community to better understand how the business operations affect the community, how the organization can contribute to improving living standards, and what types of indicators should be used to measure improvements in people's quality of life [21]. Hence, the bottom-up approach provides a systematic way of engaging community stakeholders that are often overlooked. This is where most of the secondary stakeholders' [39] or the latent and expectant stakeholders' [43] needs and expectations identified in this case study would be translated into strategic CSR goals and business processes.

'Do the right things' [34] will be achieved by a regular interaction with the company's stakeholders, with the purpose of acquiring knowledge about their needs and expectations. In a management system, a record of aspects should be generated [61], which in this case is represented by the sustainability aspect matrix, where needs and expectations are transformed into sustainability aspects, as shown in 
Appendix B. The matrix should be updated regularly after stakeholder interaction and become more detailed over time.

The 'significant' sustainability aspects are those that have, or can have, significant impact and are determined by the 'systemization of stakeholder demands' [21]. The company evaluated the aspects based on business success and the stakeholders on perceived importance, and the significant sustainability aspects are found in the upper right-hand corners in Figure 3, Figure 6, and Figure 9. However, as in this case social acceptance is in focus, we also regard the aspects in the upper left-hand corner as significant. The study shows that a materiality analysis can be used advantageously for the 'systemization of stakeholder demands' [21] in the planning step of an SMS.

Hence, this case study shows how the planning step in an SMS for social acceptance can unfold in practice.

\section{Conclusions}

The purpose of this study has been to describe a mining company's existing stakeholder management practice and to identify areas for improvement by using established stakeholder management models in order to achieve an efficient and effective stakeholder management practice. The result shows that in all three cases, more detailed stakeholder maps were generated during the workshops than the theory suggests. The strategic and operational company levels have in many cases suggested the same stakeholder groups. Our conclusion is that business organizations should carefully consider which stakeholders should be managed at the respective business level in order to create more structured and efficient stakeholder management.

Increased stakeholder pressure from society [6,7] has forced companies to develop their social responsibility practices [59]. However, our study shows that most of the community stakeholders are valued as secondary stakeholders [39], or as latent and expectant stakeholders [43] by the management groups. Our recommendation for business organizations is to understand the importance of community stakeholders (as primary stakeholders) if they want to gain social acceptance.

The level of interaction with stakeholders was evaluated in the next case study step. The findings show that all three management groups estimated the communication with primary stakeholders as extensive. However, most of the community stakeholders were evaluated as secondary stakeholders, despite the fact that they are important for social acceptance. Therefore, our conclusion is that business organizations should evaluate the interaction with stakeholders and if the interaction with community stakeholders is perceived as scarce, develop new strategies for communication with the community stakeholder groups.

The estimation of "who and what really counts" [43], where the stakeholder groups were evaluated based on the three relationship attributes of power, legitimacy, and urgency, gave almost the same result as the two-tier stakeholder map [39]. However, the estimation of "who and what really counts" [43] gives a more detailed and profound result and is therefore the model we recommend.

Materiality analyses were developed based on the result from when the management groups estimated the significance of stakeholders' needs and expectations for business success [50] and the results from the stakeholder survey and the interviews. In the materiality analyses, the 'significant' sustainability aspects are found in the upper right-hand corner. However, we would also like to point out that if business organizations strive for social acceptance, they should also pay attention to the aspects in the upper left-hand corner. This study shows that materiality analysis can advantageously be used to determine the relevance and significance of sustainability aspects, which strengthens our second proposition.

The purpose of this study has also been to describe how conceptual SMS frameworks could be usefully applied in practice and, more specifically, whether and how the stakeholder management models could be advantageous for the planning step in an SMS for social acceptance. Based on the findings, our conclusion is that the SMS framework presented by Asif et al. [21] would fit well in a mining industry context, which strengthens our first proposition. 
Hence, this case study shows how the planning step in an SMS for social acceptance can unfold in practice. Future research should preferably study how the following steps can be integrated into existing IMS and implemented into daily, ongoing business. The "integrated management systems maturity model" developed by Domingues et al. [51] can be used to evaluate the stage of evolution [62]. Another interesting aspect of SMS is connected to the monitoring and measurement of sustainability aspects, and especially to the development of qualitative key performance indicators (KPI) in main subjects that are traditionally not covered by the IMS. Finally, future research should study whether an SMS creates enhanced sustainability performance and continual improvements. In order to better understand the relationship between the maturity of the integration of SMS and sustainable performance, the framework presented by Poltronieri et al. [52] can be applied [63].

Some limitations have been identified during the case study. For example, the management groups interpreted some of the workshop instructions differently. This was not noticed until the complete workshop results were presented to the management groups. If this had been detected earlier, the workshop instructions could have been adjusted.

Author Contributions: Data collection and Analysis, H.R. and Å.L.; Conceptualization, H.R.; Data curation, Å.L.; Formal analysis, H.R. and Å.L.; Funding acquisition, H.R.; Methodology, H.R.; Project administration, H.R.; Writing - review \& editing, Å.L. All authors have read and agreed to the published version of the manuscript.

Funding: This research was funded by the Swedish innovation agency Vinnova, grant number 2017-02199.

Acknowledgments: This work was conducted as a part of the Strategic innovation programme STRIM, a joint venture by Vinnova, Formas, and the Swedish Energy Agency.

Conflicts of Interest: The authors declare no conflict of interest.

\section{Appendix A}

Table A1. A List of the international CSR frameworks and the scientific papers reviewed.

International CSR Frameworks
Global goals for sustainable development
UN Global Compact
ILO Declaration on fundamental principles and rights at work
UN The universal declaration of human rights
UN Convention against corruption
UN Guiding principles on business and human rights
OECD Principles of corporate governance
OECD Guidelines for multinational enterprises
The extractive industries transparency initiative. The EITI principles
The mining association of Canada. TSM Guiding principles
International council on mining \& metals. Sustainable development framework
Voluntary principles on security and human rights
Global reporting initiative (GRI)
GRI. Mining and metals supplement
AccountAbility 1000
Social Accountability 8000
ISO 14001 Environmental management systems
ISO 26000 Guidance on social responsibility
ISO 9001:2015 Quality management systems - requirements
OHSAS 18001 Occupational health and safety management systems - requirements
SGE-21. Forética. Ethical and socially responsible management system
UNE 22470 Sustainable mining management indicators


Table A1. Cont.

The conflict free gold standard. World gold council.

ISO 31000 Risk management standard

Carbon disclosure project

Finnish TSM standard

\begin{tabular}{c}
\hline Academic literature regarding sustainability criteria, aspects and indicators \\
\hline Ranängen et al. (2017) \\
Yaylaci et al. (2017) \\
Yaylaci et al. (2016) \\
Worrall et al. (2009) \\
Kopacz et al. (2017) \\
Diaz-Sarachaga et al. (2017) \\
Chen et al. (2015) \\
Lodhia et al. (2014) \\
Falck et al. (2014) \\
Azapagic et al. (2010) \\
Marnika et al. (2015) \\
Azapagic (2004)
\end{tabular}

\section{Appendix B}

Table A2. Company and stakeholder grading.

\begin{tabular}{|c|c|c|c|c|c|c|}
\hline \multirow{2}{*}{$\begin{array}{c}\begin{array}{c}\text { Main subjects and } \\
\text { sustainability aspects }\end{array} \\
\text { 1. The environment }\end{array}$} & \multirow[t]{2}{*}{ Description } & \multicolumn{3}{|c|}{$\begin{array}{l}\text { Company } \\
\text { Grade 1-5 }\end{array}$} & \multicolumn{2}{|c|}{$\begin{array}{l}\text { Stakeholder } \\
\text { Grade 1-5 }\end{array}$} \\
\hline & & $x$ & Mine 1 & Mine 2 & Mean & Std.Dev \\
\hline 1.1 Resource use of materials & $\begin{array}{l}\text { Efficiency in the use of materials to } \\
\text { reduce the environmental impact. }\end{array}$ & 4 & 5 & 5 & 4.5 & 0.7 \\
\hline 1.2 Resource use of energy & $\begin{array}{l}\text { Energy use and efficiency, use of fossil } \\
\text { fuels and renewable. }\end{array}$ & 4 & 5 & 3 & 4.5 & 0.7 \\
\hline 1.3 Resource use of water & Water use and efficiency. & 4 & 5 & 5 & 4.8 & 0.5 \\
\hline 1.4 Land use & $\begin{array}{l}\text { Land requirements for mineral-related } \\
\text { activities. Using land sustainably. }\end{array}$ & 5 & 5 & 5 & 4.5 & 0.8 \\
\hline 1.5 Emissions to air & $\begin{array}{l}\text { Emissions to air of pollutants such as } \\
\text { metals, VOCs, sulphur oxides, nitrogen } \\
\text { oxides, dioxins, particulates and } \\
\text { ozone-depleting substances. }\end{array}$ & 4 & 4 & 4 & 4.6 & 0.7 \\
\hline 1.6 Effluents to water & $\begin{array}{l}\text { Direct, intentional or accidental } \\
\text { discharges into water bodies. }\end{array}$ & 5 & 5 & 5 & 4.8 & 0.5 \\
\hline 1.7 Waste & $\begin{array}{l}\text { Tailings management. Responsible } \\
\text { waste management seeks avoidance of } \\
\text { waste through source reduction, reuse, } \\
\text { recycling and reprocessing, waste } \\
\text { treatment and waste disposal. }\end{array}$ & 5 & 5 & 5 & 4.8 & 0.5 \\
\hline $\begin{array}{l}1.8 \text { Toxic and hazardous } \\
\text { chemicals and materials }\end{array}$ & $\begin{array}{l}\text { The use and disposal of toxic and } \\
\text { hazardous chemicals and materials. }\end{array}$ & 5 & 3 & 5 & 4.7 & 0.6 \\
\hline 1.9 Transport & & 3 & 5 & 4 & 4.3 & 0.9 \\
\hline 1.10 Ecosystem services & $\begin{array}{l}\text { Valuing, protecting and restoring } \\
\text { ecosystem services. }\end{array}$ & 3 & 1 & 3 & 4.4 & 0.7 \\
\hline 1.11 Biodiversity & $\begin{array}{l}\text { Valuing and protecting biodiversity. The } \\
\text { extent to which the extractive activities } \\
\text { affect habitats and species. }\end{array}$ & 5 & 4 & 3 & 4.3 & 0.9 \\
\hline $\begin{array}{l}1.12 \text { Climate change } \\
\text { mitigation and adoption }\end{array}$ & $\begin{array}{l}\text { Minimizing GHG emissions and } \\
\text { planning for a changing climate. }\end{array}$ & 4 & 4 & 2 & 4.4 & 0.9 \\
\hline $\begin{array}{l}1.13 \text { Closure and } \\
\text { rehabilitation }\end{array}$ & $\begin{array}{l}\text { Pace of restoration and the level of } \\
\text { commitment to rehabilitation. }\end{array}$ & 5 & 5 & 5 & 4.5 & 0.8 \\
\hline 1.14 Recycling & For example the recycling of metals. & 0 & 5 & 4 & 4.6 & 0.6 \\
\hline
\end{tabular}


Table A2. Cont.

\begin{tabular}{|c|c|c|c|c|c|c|}
\hline \multirow{2}{*}{$\begin{array}{c}\begin{array}{c}\text { Main subjects and } \\
\text { sustainability aspects }\end{array} \\
\text { Mean value }\end{array}$} & \multirow[t]{2}{*}{ Description } & \multicolumn{3}{|c|}{$\begin{array}{l}\text { Company } \\
\text { Grade 1-5 }\end{array}$} & \multicolumn{2}{|c|}{$\begin{array}{l}\text { Stakeholder } \\
\text { Grade 1-5 }\end{array}$} \\
\hline & & 4,4 & 4,3 & 4,2 & 4.5 & 0.5 \\
\hline 2. Labour practices & & $x$ & Mine 1 & Mine 2 & Mean & Std.Dev \\
\hline $\begin{array}{l}2.1 \text { Employment and decent } \\
\text { working conditions }\end{array}$ & $\begin{array}{l}\text { Full and secure employment and decent } \\
\text { working conditions. }\end{array}$ & 4 & 4 & 5 & 4.4 & 0.7 \\
\hline 2.2 Training and education & $\begin{array}{l}\text { Human development and training in the } \\
\text { workplace. }\end{array}$ & 4 & 5 & 5 & 4.3 & 0.8 \\
\hline $\begin{array}{l}\text { 2.3 Labour/management } \\
\text { relations }\end{array}$ & $\begin{array}{l}\text { Social dialogue between employer and } \\
\text { worker. }\end{array}$ & 4 & 4 & 5 & 4.2 & 0.8 \\
\hline $\begin{array}{l}2.4 \text { Occupational health and } \\
\text { safety }\end{array}$ & $\begin{array}{l}\text { The promotion and maintenance of the } \\
\text { highest degree of physical, mental and } \\
\text { social wellbeing of workers and } \\
\text { prevention of harm to health caused by } \\
\text { working conditions. }\end{array}$ & 5 & 5 & 5 & 4.5 & 0.8 \\
\hline 2.5 Diversity & Promote diversity of the workforce. & 4 & 2 & 3 & 3.8 & 1.0 \\
\hline 2.6 Remuneration & $\begin{array}{l}\text { Provide wages and other forms of } \\
\text { remuneration in accordance with } \\
\text { national laws, regulations or collective } \\
\text { agreements. Equal Remuneration for } \\
\text { women \& men. }\end{array}$ & 5 & 2 & 5 & 4.7 & 0.7 \\
\hline 2.7 Equality & Gender equality. & 5 & 0 & 5 & 4.7 & 0.7 \\
\hline 2.8 Suppliers and contractors & & 4 & 4 & 5 & 4.4 & 0.8 \\
\hline $\begin{array}{l}\text { 2.9 National and religious } \\
\text { traditions }\end{array}$ & $\begin{array}{l}\text { Allowing national and religious } \\
\text { traditions and customs. }\end{array}$ & 3 & 0 & 1 & 3.1 & 1.2 \\
\hline Mean value & & 4.0 & 3.8 & 4.4 & 4.2 & 0.6 \\
\hline 3. Economic aspects & & $x$ & Mine 1 & Mine 2 & Mean & Std.Dev \\
\hline 3.1 Economic performance & $\begin{array}{l}\text { Direct economic value generated and } \\
\text { distributed. Revenue minus expenses } \\
\text { such as salary, interest, tax and } \\
\text { investment. }\end{array}$ & 4 & 5 & 5 & 4.4 & 0.8 \\
\hline 3.2 Direct job creation & Jobs created in the mining industry. & 3 & 2 & 3 & 4.3 & 0.8 \\
\hline 3.3 Indirect job creation & $\begin{array}{l}\text { Jobs created by suppliers, entrepreneurs, } \\
\text { etc. }\end{array}$ & 3 & 2 & 3 & 4.0 & 0.8 \\
\hline 3.4 Indirect economic impact & $\begin{array}{l}\text { Jobs created that are not related to the } \\
\text { mining industry for example hotels, } \\
\text { restaurants, shops etc. }\end{array}$ & 3 & 2 & 3 & 3.8 & 0.9 \\
\hline 3.5 Local wealth creation & To hire local labour, purchase locally etc. & 4 & 3 & 3 & 4.3 & 0.9 \\
\hline Mean value & & 3.4 & 2.8 & 3.4 & 4.2 & 0.7 \\
\hline 4 Ethical conduct & & $x$ & Mine 1 & Mine 2 & Mean & Std.Dev \\
\hline 4.1 Anti-corruption & $\begin{array}{l}\text { Examples of corruption are bribery, } \\
\text { conflicts of interest, fraud, money } \\
\text { laundering, embezzlement, concealment, } \\
\text { the obstruction of justice and trading in } \\
\text { influence. }\end{array}$ & 5 & 5 & 5 & 4.7 & 0.7 \\
\hline $\begin{array}{l}4.2 \text { Responsible political } \\
\text { involvement }\end{array}$ & $\begin{array}{l}\text { Support political processes and } \\
\text { encourage the development of public } \\
\text { policy that benefits society. Prohibit use } \\
\text { of undue influence and avoid behaviour } \\
\text { such as manipulation, intimidation and } \\
\text { coercion that undermine the public } \\
\text { political process. }\end{array}$ & 5 & 1 & 2 & 4.0 & 1.0 \\
\hline 4.3 Fair competition & $\begin{array}{l}\text { Fair and widespread competition } \\
\text { stimulates innovation and efficiency. } \\
\text { Prohibit price fixing, bid rigging, } \\
\text { predatory pricing etc. }\end{array}$ & 4 & 5 & 3 & 4.5 & 0.7 \\
\hline $\begin{array}{l}4.4 \text { Responsible supply chain } \\
\text { management }\end{array}$ & $\begin{array}{l}\text { Includes sustainable procurement } \\
\text { practice, economic procurement practice, } \\
\text { supplier assessment (human rights, } \\
\text { labour practice, impact on society, } \\
\text { environment). } \\
\text { Safety of supply to meet the demand for } \\
\text { the product in a close, medium or distant } \\
\text { environment. }\end{array}$ & 5 & 4 & 3 & 4.5 & 0.7 \\
\hline
\end{tabular}


Table A2. Cont.

\begin{tabular}{|c|c|c|c|c|c|c|}
\hline \multirow{2}{*}{$\begin{array}{c}\begin{array}{c}\text { Main subjects and } \\
\text { sustainability aspects }\end{array} \\
\text { Mean value }\end{array}$} & \multirow[t]{2}{*}{ Description } & \multicolumn{3}{|c|}{$\begin{array}{l}\text { Company } \\
\text { Grade 1-5 }\end{array}$} & \multicolumn{2}{|c|}{$\begin{array}{l}\text { Stakeholder } \\
\text { Grade 1-5 }\end{array}$} \\
\hline & & 4.8 & 4.0 & 3.6 & 4.4 & 0.6 \\
\hline 5. Human rights & & $X$ & Mine 1 & Mine 2 & Mean & Std.Dev \\
\hline 5.1 Non-discrimination & $\begin{array}{l}\text { The elimination of all forms of } \\
\text { discrimination. }\end{array}$ & 4 & 2 & 5 & 4.7 & 0.5 \\
\hline $\begin{array}{l}5.2 \text { Freedom of association } \\
\text { and collective bargaining }\end{array}$ & $\begin{array}{l}\text { Workers and employers have the right to } \\
\text { establish and to join organizations of } \\
\text { their own choosing without previous } \\
\text { authorization. Representative } \\
\text { organizations formed } \\
\text { or joined by workers should be } \\
\text { recognized for purposes of collective } \\
\text { bargaining. }\end{array}$ & 5 & 0 & 5 & 4.5 & 0.7 \\
\hline 5.3 Child labour & $\begin{array}{l}\text { Abolishment of child labour. The } \\
\text { minimal age of employment is } \\
\text { determined through international } \\
\text { instruments. }\end{array}$ & 5 & 0 & 0 & 4.8 & 0.7 \\
\hline $\begin{array}{l}5.4 \text { Forced or compulsory } \\
\text { labour }\end{array}$ & $\begin{array}{l}\text { Not engage or benefit from use of forced } \\
\text { or compulsory labour. }\end{array}$ & 5 & 0 & 0 & 4.8 & 0.7 \\
\hline 5.5 Indigenous rights & $\begin{array}{l}\text { Indigenous peoples have experienced } \\
\text { systemic discrimination, such as } \\
\text { colonization, dispossession of their land, } \\
\text { separate status from other citizens and } \\
\text { violations of their human rights. From a } \\
\text { Nordic perspective, this issue is often } \\
\text { linked to the Sami people. }\end{array}$ & 4 & 4 & 0 & 3.9 & 1.2 \\
\hline 5.6 Civil and political rights & $\begin{array}{l}\text { Life and liberty, equality before the law } \\
\text { and freedom of expression. }\end{array}$ & 5 & 0 & 0 & 4.7 & 0.5 \\
\hline $\begin{array}{l}5.7 \text { Economic, social and } \\
\text { cultural rights }\end{array}$ & $\begin{array}{l}\text { Right to work, to food, health, education } \\
\text { and social security. }\end{array}$ & 0 & 0 & 0 & 4.3 & 0.8 \\
\hline Mean value & & 4.4 & 2.7 & 3.7 & 4.5 & 0.5 \\
\hline 6. Society & & $x$ & Mine 1 & Mine 2 & Mean & Std.Dev \\
\hline $\begin{array}{l}6.1 \text { Involvement and } \\
\text { development in the local } \\
\text { communities }\end{array}$ & $\begin{array}{l}\text { Proactive outreach to the community. } \\
\text { Preventing or solving problems, } \\
\text { fostering partnerships with local } \\
\text { organizations and stakeholders. }\end{array}$ & 4 & 3 & 4 & 4.4 & 0.7 \\
\hline 6.2 Public participation & & 3 & 2 & 5 & 4.1 & 0.8 \\
\hline $\begin{array}{l}\text { 6.3 Resettlement of } \\
\text { communities/households }\end{array}$ & $\begin{array}{l}\text { Minimise involuntary resettlement, and } \\
\text { compensate fairly for adverse effects on } \\
\text { the community where resettlement } \\
\text { cannot be avoided. }\end{array}$ & 3 & 5 & 0 & 4.2 & 1.0 \\
\hline $\begin{array}{l}\text { 6.4 Grievance mechanisms } \\
\text { for impacts on society }\end{array}$ & & 3 & 2 & 2 & 4.3 & 0.7 \\
\hline 6.5 Education & $\begin{array}{l}\text { Promote and support education at all } \\
\text { levels. }\end{array}$ & 2 & 3 & 4 & 4.0 & 0.9 \\
\hline 6.6 Culture and art & $\begin{array}{l}\text { Help conserve and protect cultural } \\
\text { heritage. }\end{array}$ & 2 & 2 & 1 & 3.4 & 1.1 \\
\hline $\begin{array}{l}6.7 \text { Technology development } \\
\text { and access }\end{array}$ & $\begin{array}{l}\text { Include science and technology, } \\
\text { infrastructure development. }\end{array}$ & 0 & 1 & 1 & 3.9 & 1.0 \\
\hline $\begin{array}{l}6.8 \text { Wealth and income } \\
\text { creation }\end{array}$ & $\begin{array}{l}\text { Entrepreneurship programmes, local } \\
\text { suppliers, employment of community } \\
\text { members, tax obligations, economic } \\
\text { resources and social relations. }\end{array}$ & 3 & 2 & 4 & 4.2 & 0.7 \\
\hline 6.9 Public health & $\begin{array}{l}\text { A healthy community reduces the } \\
\text { burden on the public sector and } \\
\text { contributes to a good economic and } \\
\text { social environment. }\end{array}$ & 3 & 2 & 3 & 4.4 & 0.9 \\
\hline 6.10 Health impacts & $\begin{array}{l}\text { Eliminate negative health impacts of } \\
\text { production process, product or service. }\end{array}$ & 5 & 5 & 5 & 4.6 & 0.5 \\
\hline
\end{tabular}


Table A2. Cont.

\begin{tabular}{|c|c|c|c|c|c|c|}
\hline $\begin{array}{c}\text { Main subjects and } \\
\text { sustainability aspects }\end{array}$ & Description & & $\begin{array}{l}\text { Company } \\
\text { Grade 1-5 }\end{array}$ & & Sta & $\begin{array}{l}\text { older } \\
1-5\end{array}$ \\
\hline $\begin{array}{l}6.11 \text { Geotechnical hazards } \\
\text { and accidents }\end{array}$ & $\begin{array}{l}\text { Industrial emergencies, natural disasters, } \\
\text { medical emergencies, environmental } \\
\text { releases, political and security risks etc. }\end{array}$ & 5 & 5 & 5 & 4.8 & 0.4 \\
\hline 6.12 Social equality & & 0 & 1 & 0 & 4.5 & 0.7 \\
\hline 6.13 Community safety & & 0 & 1 & 3 & 4.0 & 0.9 \\
\hline 6.14 Social investment & $\begin{array}{l}\text { Social investments that improve social } \\
\text { aspects of community life and can be } \\
\text { related to education, training, culture, } \\
\text { health care, income generation, } \\
\text { infrastructure development etc. }\end{array}$ & 3 & 2 & 4 & 3.9 & 1.0 \\
\hline 6.15 Nuisance & $\begin{array}{l}\text { The level of nuisance for neighbouring } \\
\text { communities. Visual, noise, dust, } \\
\text { vibrations, odour, light pollution, } \\
\text { radiation etc. }\end{array}$ & 4 & 4 & 2 & 4.6 & 0.7 \\
\hline Mean value & & 4.4 & 2.7 & 3.7 & 4.2 & 0.5 \\
\hline 7. Corporate governance & & $x$ & Mine 1 & Mine 2 & Mean & Std.Dev \\
\hline 7.1 Stakeholder management & $\begin{array}{l}\text { Dialogue between the organization and } \\
\text { stakeholders for an informed basis for its } \\
\text { decisions. }\end{array}$ & 4 & 4 & 5 & 4.4 & 0.7 \\
\hline 7.2 Respect for the rule of law & $\begin{array}{l}\text { An organization should accept that } \\
\text { respect for the rule of law is mandatory. } \\
\text { Includes the general consideration rules. }\end{array}$ & 5 & 5 & 5 & 4.9 & 0.3 \\
\hline $\begin{array}{l}7.3 \text { Respect for international } \\
\text { norms of behaviour }\end{array}$ & $\begin{array}{l}\text { An organization should respect } \\
\text { international norms of behaviour, while } \\
\text { adhering to the principle of respect for } \\
\text { the rule of law. }\end{array}$ & 4 & 3 & 3 & 4.7 & 0.6 \\
\hline $\begin{array}{l}7.4 \text { Self-regulatory practices } \\
\text { and management systems }\end{array}$ & $\begin{array}{l}\text { Developing and applying self-regulatory } \\
\text { practices and management systems that } \\
\text { foster confidence and mutual trust } \\
\text { between enterprises and the societies in } \\
\text { which they operate. }\end{array}$ & 5 & 5 & 4 & 4.6 & 0.6 \\
\hline 7.5 Disclosure & $\begin{array}{l}\text { Disclosure of information, including } \\
\text { reporting. }\end{array}$ & 3 & 2 & 5 & 4.4 & 0.7 \\
\hline $\begin{array}{l}7.6 \text { Risk assessment (risk } \\
\text { management) }\end{array}$ & $\begin{array}{l}\text { Risk management involves various } \\
\text { methods for managing the effect of } \\
\text { uncertainty on a company's objectives, } \\
\text { i.e. managing risk by detecting and } \\
\text { understanding risk and modifying it } \\
\text { where necessary. }\end{array}$ & 5 & 5 & 5 & 4.6 & 0.7 \\
\hline \multicolumn{2}{|l|}{ Mean value } & 4.3 & 4.0 & 4.5 & 4.5 & 0.4 \\
\hline
\end{tabular}

\section{References}

1. Dahlsrud, A. How corporate social responsibility is defined: An analysis of 37 definitions. Corp. Soc. Responsib. Environ. Manag. 2008, 15, 1-13. [CrossRef]

2. Ashrafi, M.; Magnan, G.M.; Adams, M.; Walker, T.R. Understanding the conceptual evolutionary path and theoretical underpinnings of corporate social responsibility and corporate sustainability. Sustainability 2020, 12, 760. [CrossRef]

3. Michelon, G.; Pilonato, S.; Ricceri, F. CSR reporting practices and the quality of disclosure: An empirical analysis. Crit. Perspect. Account. 2015, 33, 59-78. [CrossRef]

4. Farcane, N.; Deliu, D.; Bureana, E. A corporate case study: The application of Rokeach's value system to corporate social responsibility (CSR). Sustainability 2019, 11, 6612. [CrossRef]

5. Moran, C.J.; Lodhia, S.; Kunz, N.C.; Huisingh, D. Sustainability in mining, minerals and energy: New processes, pathways and human interactions for a cautiously optimistic future. J. Clean. Prod. 2014, 84, 1-15. [CrossRef]

6. Mele, D. The Oxford Handbook of Corporate Social Responsibility; Oxford University Press: New York, NY, USA, 2008.

7. Kapelus, P. Mining, corporate social responsibility and the "community": The case of Rio Tinto, Richards Bay Minerals and the Mbonambi. J. Bus. Ethics 2002, 39, 275-296. [CrossRef] 
8. Ranängen, H.; Zobel, T. Exploring the path from management systems to stakeholder management in the Swedish mining industry. J. Clean. Prod. 2014, 84, 128-141. [CrossRef]

9. Sairinen, R.; Tiainen, H.; Mononen, T. Talvivaara mine and water pollution: An analysis of mining conflict in Finland. Extract. Ind. Soc. 2017, 4, 640-651. [CrossRef]

10. Ranängen, H.; Lindman, Å. Exploring corporate social responsibility practice versus stakeholder interests in Nordic mining. J. Clean. Prod. 2018, 197, 668-677. [CrossRef]

11. Thorén Hedin, L.; Ranängen, H. Community involvement and development in Swedish mining. Extract. Ind. Soc. 2017, 4, 630-639. [CrossRef]

12. Owen, J.R.; Kemp, D. Social licence and mining: A critical perspective. Resour. Policy 2013, 38, $29-35$. [CrossRef]

13. Prno, J.; Slocombe, S. Exploring the origins of 'social license to operate' in the mining sector: Perspectives from governance and sustainability theories. Resour. Policy 2012, 37, 346-357. [CrossRef]

14. Lesser, P.; Suopajärvi, L.; Koivurova, T. Challenges that mining companies face in gaining and maintaining a social licence to operate in Finnish Lapland. Mineral Econ. 2017, 30, 41-51. [CrossRef]

15. Mzembe, A.N.; Meaton, J. Driving corporate social responsibility in the Malawian mining industry; A stakeholder perspective. Corp. Soc. Responsib. Environ. Manag. 2013, 21, 189-201. [CrossRef]

16. Prno, J. An analysis of factors leading to the establishment of a social license to operate in the mining industry. Resour. Policy 2013, 38, 577-590. [CrossRef]

17. Que, S.; Wang, L.; Awuah-Offei, K.; Yang, W.; Jiang, H. Corporate Social Responsibility: Understanding the Mining Stakeholder with a Case Study. Sustainability 2019, 11, 2407. [CrossRef]

18. Bice, $\mathrm{S}$. What gives you a social licence? An exploration of the social licence to operate in the Australian mining industry. Resources 2014, 3, 62-80. [CrossRef]

19. Mercer-Mapstone, L.; Rifkin, W.; Louis, W.R.; Moffat, K. Company-community dialogue builds relationships, fairness, and trust leading to social acceptance of Australian mining developments. J. Clean. Prod. 2018, 184, 671-677. [CrossRef]

20. Ranängen, H.; Lindman, Å. A path towards sustainability for the Nordic mining industry. J. Clean. Prod. 2017, 151, 43-52. [CrossRef]

21. Asif, M.; Searcy, C.; Zutshi, A.; Fisscher, O. An integrated management systems approach to corporate social responsibility. J. Clean. Prod. 2013, 56, 7-17. [CrossRef]

22. Shahin, A.; Zairi, M. Corporate governance as a critical element for driving excellence in corporate social responsibility. Int. J. Qual. Reliab. Manag. 2007, 24, 753-770. [CrossRef]

23. Castka, P.; Bamber, C.J.; Bamber, D.J.; Sharp, J.M. Integrating corporate social responsibility (CSR) into ISO management systems-In search of a feasible CSR management system framework. TQM Mag. 2004, 16, 216-224. [CrossRef]

24. Azapagic, A. Systems approach to corporate sustainability: A general management framework. Process Saf. Environ. Prot. 2003, 81, 303-316. [CrossRef]

25. Kemp, D. Community relations in the global mining industry: Exploring the internal dimensions of externally orientated work. Corp. Soc. Responsib. Environ. Manag. 2010, 17, 1-14. [CrossRef]

26. Herghiligiu, I.V.; Robu, I.-B.; Pislaru, M.; Vilcu, A.; Asandului, A.L.; Avasilcăi, S.; Balan, C. Sustainable environmental management system integration and business performance: A balance assessment approach using fuzzy logic. Sustainability 2019, 11, 5311. [CrossRef]

27. Esquer-Peralta, J.; Velazquez, L.; Munguia, N. Perceptions of core elements for sustainability management systems (SMS). Sustain. Manag. Decis. 2008, 46, 1027-1038. [CrossRef]

28. Rocha, M.; Searcy, C.; Karapetrovic, S. Integrating sustainable development into management systems. Total Qual. Manag. Bus. Excell. 2007, 18, 83-92. [CrossRef]

29. Nunhes, T.V.; Ferreira Motta, L.C.; de Oliveira, O.J. Evolution of integrated management systems research on the J. Clean. Prod.: Identification of contributions and gaps in the literature. J. Clean. Prod. 2016, 139, 1234-1244. [CrossRef]

30. Oliviera, O.J. Guidelines for the integration of certifiable management systems in industrial companies. J. Clean. Prod. 2013, 57, 124-133. [CrossRef]

31. Santos, G.; Mendes, F.; Barbosa, J. Certification and integration of management systems: The experience of Portuguese small and medium enterprises. J. Clean. Prod. 2011, 19, 1965-1974. [CrossRef] 
32. Zeng, S.X.; Shi, J.J.; Lou, G.X. A synergetic model for implementing an integrated management system: An empirical study in China. J. Clean. Prod. 2007, 15, 1760-1767. [CrossRef]

33. Könnölä, T.; Unruh, G. Really changing the course: The limitations of environmental management systems for innovation. Bus. Strategy Environ. 2007, 16, 525-537. [CrossRef]

34. Kemp, D.; Boele, R.; Brereton, D. Community relations management systems in the minerals industry: Combining conventional and stakeholder-driven approaches. Int. J. Sustain. Dev. 2006, 9, 390-403. [CrossRef]

35. Jørgensen, T.H. Towards more sustainable management systems: Through life cycle management and integration. J. Clean. Prod. 2008, 16, 1071-1080. [CrossRef]

36. Zwetsloot, G. From management systems to corporate social responsibility. J. Bus. Eth. 2003, 44, $201-207$. [CrossRef]

37. Hörisch, J.; Freeman, E.; Schaltegger, S. Applying stakeholder theory in sustainability management: Links, similarities, dissimilarities, and a conceptual framework. Org. Environ. 2014, 27, 328-346. [CrossRef]

38. Starik, M.; Marcus, A.A.; Illitch, A. Special research forum: The management of organizations in the natural environment. Acad. Manag. J. 2000, 43, 539-736.

39. Freeman, E.R.; Harrison, J.S.; Wicks, A.C. Managing for Stakeholders: Survival, Reputation, and Success; Yale University Press: New Haven, CT, USA, 2007.

40. Maas, S.; Reniers, G. Development of a CSR model for practice: Connecting five inherent areas of sustainable business. J. Clean. Prod. 2014, 64, 104-114. [CrossRef]

41. Azapagic, A.; Perdan, S. Corporate sustainability management: A methodology and a case study in the mining and minerals sector. Int. J. Min. Miner. Eng. 2010, 2, 310-337. [CrossRef]

42. Singh, R.K.; Murty, H.R.; Gupta, S.K. An approach to develop sustainability management systems in the steel industry. World Rev. Entrep. Manag. Sustain. Dev. 2007, 3, 90-108. [CrossRef]

43. Mitchell, R.K.; Agle, B.R.; Wood, D.J. Toward a theory of stakeholder identification and salience: Defining the principle of who and what really counts. Acad. Manag. Rev. 1997, 22, 853-886. [CrossRef]

44. Freeman, R.E. Strategic Management: A Stakeholder Approach; Pitman Publishing: Boston, FL, USA, 2010.

45. Agle, B.R.; Mitchell, R.K.; Sonnenfeld, J.A. Who matters to CEOs? An investigation of stakeholder attributes and salience, corporate performance, and CEO values. Acad. Manag. J. 1999, 42, 507-525.

46. ISO. Guidance on Social Responsibility; ISO 26000:2010, IDT; ISO: Geneva, Switzerland, 2010.

47. Ranängen, H. Stakeholder management theory meets CSR practice in Swedish mining. Mineral Econ. 2017, 30, 15-29. [CrossRef]

48. Ranängen, H. Stakeholder management in reality: Moving from conceptual frameworks to operational strategies and interactions. Sustain. Prod. Consum. 2015, 3, 21-33. [CrossRef]

49. Global Reporting Initiative. 2019. GRI Standards. Available online: https://www.globalreporting.org/ standards (accessed on 2 April 2019).

50. Whitehead, J. Prioritizing sustainability indicators: Using materiality analysis to guide sustainability assessment and strategy. Bus. Strategy Environ. 2017, 26, 399-412. [CrossRef]

51. Yin, R.K. Case Study Research: Design and Methods; SAGE Publications Inc.: London, UK, 2014.

52. Miles, M.B.; Huberman, A.M.; Saldaña, J. Qualitative Data Analysis: An Expanded Sourcebook; Sage Publications: Los Angeles, CA, USA, 2014.

53. Ranängen, H.; Zobel, T. Revisiting the 'how' of corporate social responsibility in extractive industries and forestry. J. Clean. Prod. 2014, 84, 299-312. [CrossRef]

54. Raufflet, E.; Cruz, L.B.; Bres, L. An assessment of corporate social responsibility practices in the mining and oil and gas industries. J. Clean. Prod. 2014, 84, 256-270. [CrossRef]

55. Hart, C. Doing a Literature Review; SAGE Publications Ltd.: London, UK, 1998.

56. Svensson, L.; Aagaard Nielsen, K. Action and Interactive Research: Beyond Practice and Theory; Shaker Publishing: Maastricht, The Netherlands, 2006.

57. Johannisson, B.; Gunnarsson, E.; Stjernberg, T. Gemensamt Kunskapande: Den Interaktiva Forskningens Praktik; Växjö University Press: Göteborg, Sweden, 2008.

58. Beske, F.; Haustein, E.; Lorson, P.C. Materiality analysis in sustainability and integrated reports. Sustain. Account. Manag. Policy J. 2019, 11, 162-186. [CrossRef]

59. Jenkins, H.; Yakovleva, N. Corporate social responsibility in the mining industry: Exploring trends in social and environmental disclosure. J. Clean. Prod. 2006, 14, 271-284. [CrossRef] 
60. Pedro, A.; Ayuk, E.T.; Bodouroglou, C.; Milligan, B.; Ekins, P.; Oberle, B. Towards a sustainable development licence to operate for the extractive sector. Mineral Econ. 2017, 30, 53-165. [CrossRef]

61. ISO. Environmental Management Systems-Requirements with Guidance for Use; ISO 14001:2015; ISO: Geneva, Switzerland, 2015.

62. Domingues, J.P.T.; Sampaio, P.; Arezes, P. Integrated management systems assessment: A maturity model proposal. J. Clean. Prod. 2016, 124, 164-174. [CrossRef]

63. Poltronieri, C.F.; Gerolamo, M.C.; Martins Dias, T.C.; Ribeiro Carpinetti, L.C. Instrument for evaluating IMS and sustainable performance. J. Qual. Reliab. Manag. 2018, 35, 373-386. [CrossRef]

(C) 2020 by the authors. Licensee MDPI, Basel, Switzerland. This article is an open access article distributed under the terms and conditions of the Creative Commons Attribution (CC BY) license (http://creativecommons.org/licenses/by/4.0/). 